\title{
Synthesis of alumina, titania, and alumina-titania hydrophobic membranes via sol-gel polymeric route
}

\author{
Amany Abd AL-Azem Gaber ${ }^{*}$, Doreya Mohamed Ibrahim, Fawzia Fahm Abd-Almohsen² \\ and Elham Mohamed El-Zanati ${ }^{3}$
}

\begin{abstract}
Nanometer $\mathrm{TiO}_{2}-\mathrm{Al}_{2} \mathrm{O}_{3}$ composite membranes were synthesized through the sol-gel polymeric reaction of $\mathrm{TiCl}_{4}$ and $\mathrm{AlCl}_{3}$ in the presence of acrylic-acrylamide copolymer as a template. The dried samples were characterized by DTA, TGA, FTIR, XRD, and TEM to determine the thermal behavior, chemical composition, crystal structure, shape, and size of the particles. Octyltrichlorosilane was chosen as a silane coupling agent to increase the hydrophobic nature of the prepared membranes. The morphological structure, hydrophobic nature, water permeability, and desalination efficiency of the prepared membranes were studied by SEM, contact angle, permeability, and $\mathrm{NaCl}$ rejection coefficient (R\%) measurements. The crystal structure of titania and alumina particles in the composite was affected by the $\mathrm{AlCl}_{3}$ and $\mathrm{TiCl}_{4}$ feed ratio. As the titania concentration increased, the average particle size of the composite particles became larger and the uniformity of the membrane layer decreased. The alumina (75\%)-titania (25\%) composite (AT25) showed a uniform crack-free membrane layer with a pore diameter of $12.9 \mathrm{~nm}$ and a porosity of $21.46 \%$, with great hydrophobic nature, and with contact angle reaching $116^{\circ}$. This membrane can withstand calcination temperature up to $700^{\circ} \mathrm{C}$, as the alumina and titania were present in their active forms: gamma-alumina and anatase, respectively. The membrane produced from this composite showed a high surface area of $333 \mathrm{~m}^{2} / \mathrm{g}$ with a respective particle size of $4.6 \mathrm{~nm}$. Moreover, it showed a high ability to reject $\mathrm{NaCl}$ from water with a rejection coefficient of $73 \%$ and a high permeation flux of $4.8 \mathrm{l} / \mathrm{h} \mathrm{m} \mathrm{m}^{2}$ at $75^{\circ} \mathrm{C}$.
\end{abstract}

\section{Background}

Ceramic membranes are gaining more and more importance in separation technology, especially in combination with catalytic processes. They have several positive merits especially their chemical resistance, thermal resistance, and high permeability (Schaep et al. 1999; van Gestel et al. 2002, 2003). The main aim of the research work in this field was the production of new nano-porous metal oxide membranes. Thus, great advances were made regarding the development of non-silicate ceramic membranes. Systems like $\mathrm{ZrO}_{2}$ and $\mathrm{TiO}_{2}$ were taken into consideration, in particular with respect to their chemical resistance (Schaep et al. 1999; van Gestel et al. 2002, 2003; Shojai and Mantyla 2001). Also, $\gamma-\mathrm{Al}_{2} \mathrm{O}_{3}$ and $\mathrm{TiO}_{2}$ were of

\footnotetext{
* Correspondence: amany1gaber@yahoo.com

${ }^{1}$ Ceramic Department, National Research Centre, Cairo, Egypt

Full list of author information is available at the end of the article
}

main interest (Xu and Anderson 1993; Larbot et al. 1994; Wildman et al. 1994; Puhlfürß et al. 2000). These membranes have high selectivity against small macromolecules. The reduction in pore size from ultrafiltration to nano-filtration range was enabled by changing the method of synthesis and the precursors used from the colloidal to the polymeric sol-gel technique.

Alumina membranes based on the application of a template polymer were produced over decades (Benfer et al. 2001; Richter et al. 1997; Benfer et al. 2004) with varying pore sizes and permeation rates. However, there was a current limitation for the practical application of these alumina membranes due to the failure in the production of a complete crack-free layer by the sol-gel technique. The partial kinetic $\gamma$ - to $\alpha$-alumina phase transformation occurs upon calcination of the alumina membrane layer at temperatures above $600^{\circ} \mathrm{C}$. Phase transformation takes place by coalescence of small ( $\gamma$-alumina) particles into 

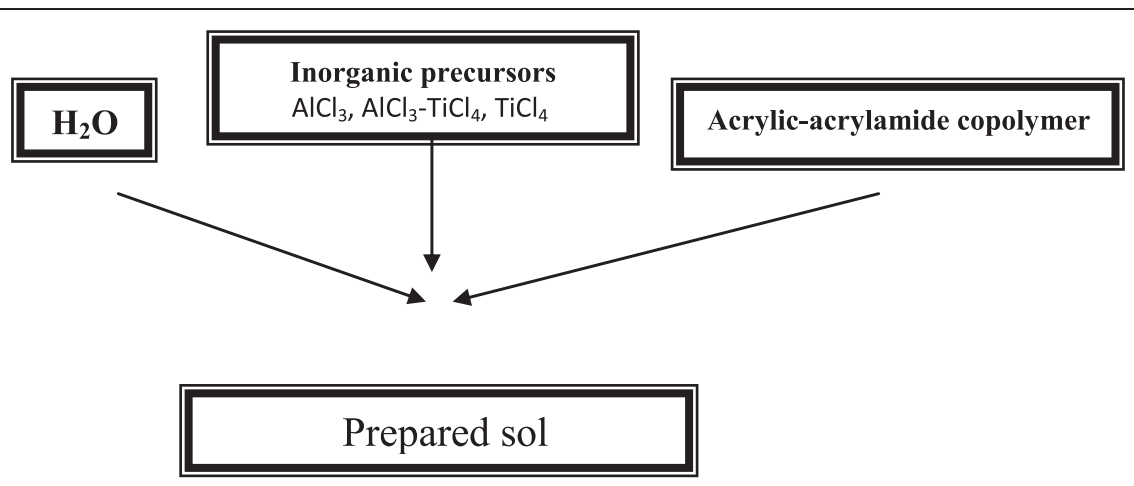

Dip-coating of porous alumina disk calcined at $1400^{\circ} \mathrm{C}$ Covered with alumina intermediate layer calcined at $1000^{\circ} \mathrm{C}$ in the prepared sol

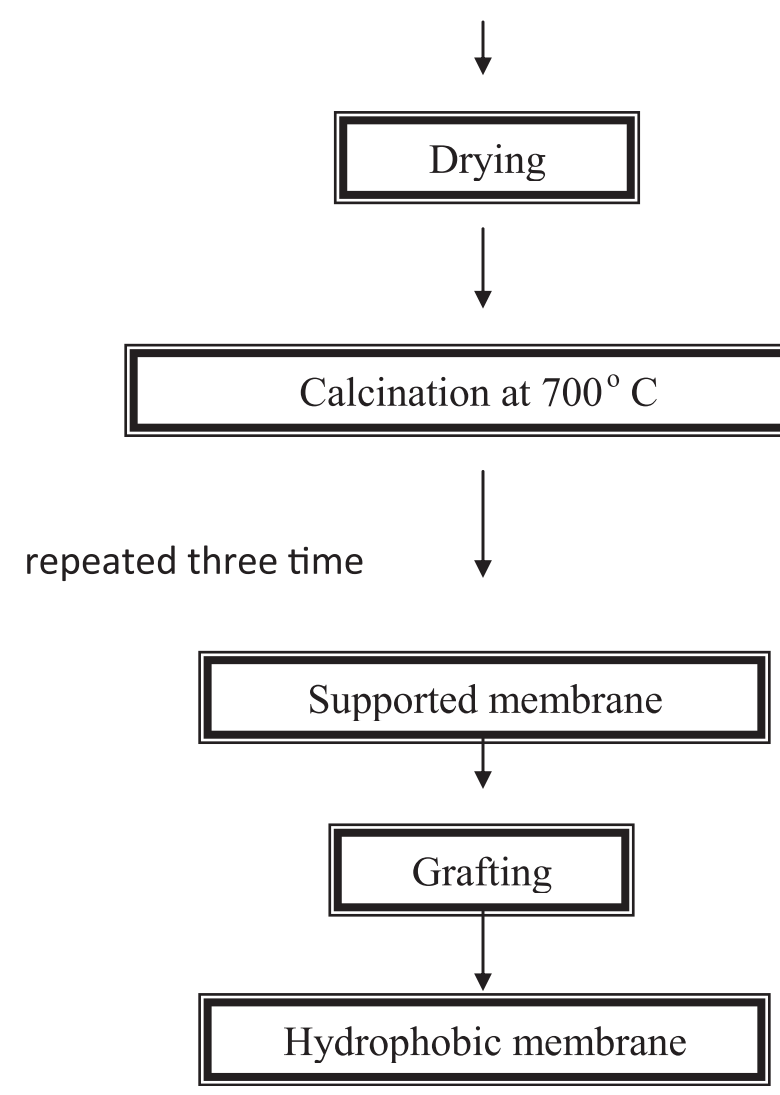

Figure 1 Steps of hydrophobic membrane layer preparation. 
larger ( $\alpha$-alumina) grains, accompanied by considerable grain and pore growth. This was practically overcome by calcination at a minimum temperature of $600^{\circ} \mathrm{C}$ to obtain well-defined, mechanically stable layers of alumina membranes (Gaber 2007). The effect of phase transformation and accompanying grain growth can be avoided as suggested by Kumar, by retarding its occurrence to a temperature above the normal calcination temperature. It has been suggested that the presence of a second phase decreases the sub-coordination number of the prepared particles in the nano-composite matrix (Sekulic et al. 2004; Kumar 1993; Zhang and Banfield 1999). The presence of titania as a second phase to form an alumina-titania composite membrane retards the $\gamma$-alumina transformation and keeps it in its amorphous phase, avoiding its transformation into $\alpha$-alumina phase; at the same time, the presence of alumina keeps the titania in its stable form as anatase phase.

The present work aims at preparing alumina-titania composite membranes that can withstand temperature up to $700^{\circ} \mathrm{C}$. The prepared membrane surfaces were modified by octyltrichlorosilane to render them hydrophobic for desalination purposes. The properties and microstructure of the prepared membranes before and after modification were characterized.

\section{Methods}

\section{Materials}

Pure chemical reagents were selected to prepare the required membranes. The following precursors were used: aluminum chloride $\left(\mathrm{AlCl}_{3}\right)$ was supplied by Aldrich (St. Louis, MO, USA), titanium chloride $\left(\mathrm{TiCl}_{4}\right)$ by Fluka Chemika (Buchs, Swizerland), aluminum hydroxide $\left(\mathrm{Al}(\mathrm{OH})_{3}\right)$ by Arabian Medical \& Scientific Lab. Sup. Co. (Dubai, United Arab Emirates), ammonium persulfate and acrylic and acrylamide monomers by Merk-Schuchardt (Darmstadt, Germany), polyvinyl alcohol by German, and octyltrichlorosilane by Aldrich.

\section{Method of preparation of the membranes}

The method of membrane preparation is demonstrated by the flow chart in Figure 1.

\section{Preparation of the acrylic-acrylamide copolymer}

Acrylic-acrylamide was polymerized on laboratory scale via a free radical method to obtain the copolymer Gaber AA (2007). Preparation of alumina membranes by solgel polymeric route 658 M.Sc Thesis, Cairo University. The following shows the reaction of formation:

$$
\begin{aligned}
& \text { Acrylic acid monomer }+ \text { Acrylamide monomer } \\
& n \mathrm{CH}_{2}=\mathrm{CH}-\mathrm{COOH} \quad n \mathrm{CH}_{2}=\mathrm{CH}-\mathrm{CO}-\mathrm{NH}_{2} \\
& \downarrow
\end{aligned}
$$

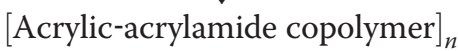

Table 1 Composition of the prepared membranes

\begin{tabular}{lcc}
\hline $\begin{array}{l}\text { Membrane } \\
\text { symbol }\end{array}$ & $\begin{array}{c}\text { Type of inorganic } \\
\text { salts }\end{array}$ & $\begin{array}{c}\text { Concentration of inorganic salts } \\
\text { (mol\%) }\end{array}$ \\
\hline $\mathrm{A}$ & $\mathrm{AlCl}_{3}$ & $100 \% \mathrm{AlCl}_{3}$ \\
$\mathrm{~T}$ & $\mathrm{TiCl}_{4}$ & $100 \% \mathrm{TiCl}_{4}$ \\
AT25 & $\mathrm{AlCl}_{3}-\mathrm{TiCl}_{4}$ & $75 \% \mathrm{AlCl}_{3}$ \\
& & $25 \% \mathrm{TiCl}_{4}$ \\
AT50 & $\mathrm{AlCl}_{3}-\mathrm{TiCl}_{4}$ & $50 \% \mathrm{AlCl}_{3}$ \\
& & $50 \% \mathrm{TiCl}_{4}$ \\
AT75 & $\mathrm{AlCl}_{3}-\mathrm{TiCl}_{4}$ & $25 \% \mathrm{AlCl}_{3}$ \\
& & $75 \% \mathrm{TiCl}_{4}$ \\
\hline
\end{tabular}

\section{Preparation of the alumina support}

Supports in the form of disks with the following dimensions: diameter $25 \mathrm{~mm}$ and thickness $2 \mathrm{~mm}$, were processed from $\alpha$-alumina powder (commercial alumina) with a mean particle size $\leq 10 \mu \mathrm{m}$ and $2 \mathrm{wt} \%$ polyvinyl alcohol as organic binder under a uniaxial press and a pressure of $200 \mathrm{MPa}$. The specimens were dried and then first fired in a muffle furnace in air at a rate of $2^{\circ} \mathrm{C} / \mathrm{min}$ up to $500^{\circ} \mathrm{C}$ and maintained for $2 \mathrm{~h}$ at this temperature to eliminate the organic binder. Heating was then continued at a rate of $4^{\circ} \mathrm{C} / \mathrm{min}$ up to $1,400^{\circ} \mathrm{C}$ for $4 \mathrm{~h}$ and then cooled to room temperature.

\section{Preparation of the alumina suspension}

Fine $\alpha$-alumina powder was first prepared by calcining chemically pure $\mathrm{Al}(\mathrm{OH})_{3}$ at $1,200^{\circ} \mathrm{C}$ for $3 \mathrm{~h}$. The obtained powder was used to prepare a homogeneous and stable suspension by the addition of $0.5 \mathrm{ml}$ of ammonia solution, $10 \mathrm{~g}$ of acrylic-acrylamide copolymer, and $6.6 \mathrm{~g}$ of $3.5 \mathrm{wt} \%$ polyvinyl alcohol solution; $1.08 \mathrm{~g}$ of this dispersing agent was added to $1 \mathrm{~g}$ of the calcined $\alpha$-alumina powder and well stirred for $1 \mathrm{~h}$, followed by dispersing in an ultrasonic bath for another $1 \mathrm{~h}$.

The prepared suspension was poured on the surface of the alumina support, homogenized to form a uniform layer of about $3 \mu \mathrm{m}$ thick, dried for $24 \mathrm{~h}$ at $80^{\circ} \mathrm{C}$, and then fired at $1,000^{\circ} \mathrm{C}$ for $3 \mathrm{~h}$ at a heating rate of $1.5^{\circ} \mathrm{C} / \mathrm{min}$.

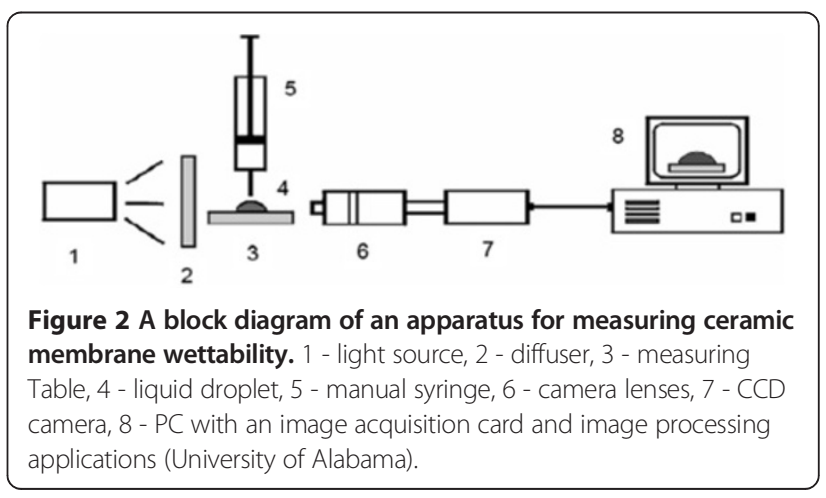




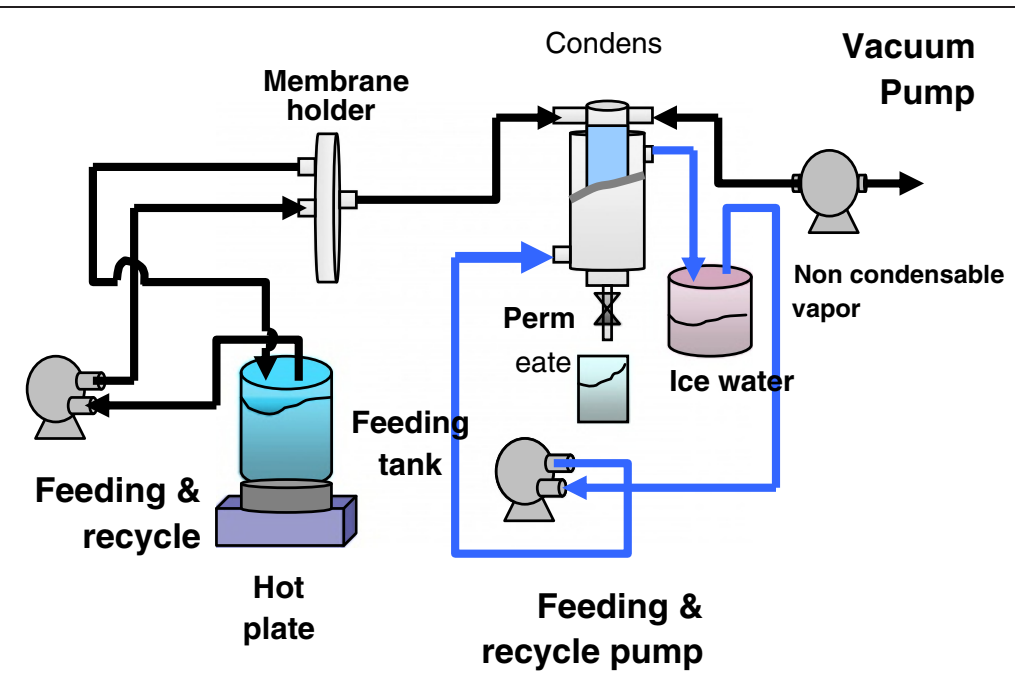

Figure 3 Vacuum membrane distillation system (flow diagram).

\section{Preparation of the membrane layer}

The salt solution of $\mathrm{AlCl}_{3}$ and $\mathrm{TiCl}_{4}$ (alumina $100 \%$ and titania $100 \%$ ) as well as $\mathrm{AlCl}_{3}-\mathrm{TiCl}_{4}$ mixed oxides (75\%:25\%, 50\%:50\%, and 25\%:75\%) were prepared by dissolving the calculated ratio equivalent to $12 \mathrm{~mol}$. The prepared solid solutions were added dropwise to an equivalent weight of $1 \mathrm{~mol}$ of the acrylic-acrylamide monomer that was kept constant in all batches as demonstrated in Table 1 . The reaction proceeds at room temperature in an acidic media at $\mathrm{pH} 3$ with continuous

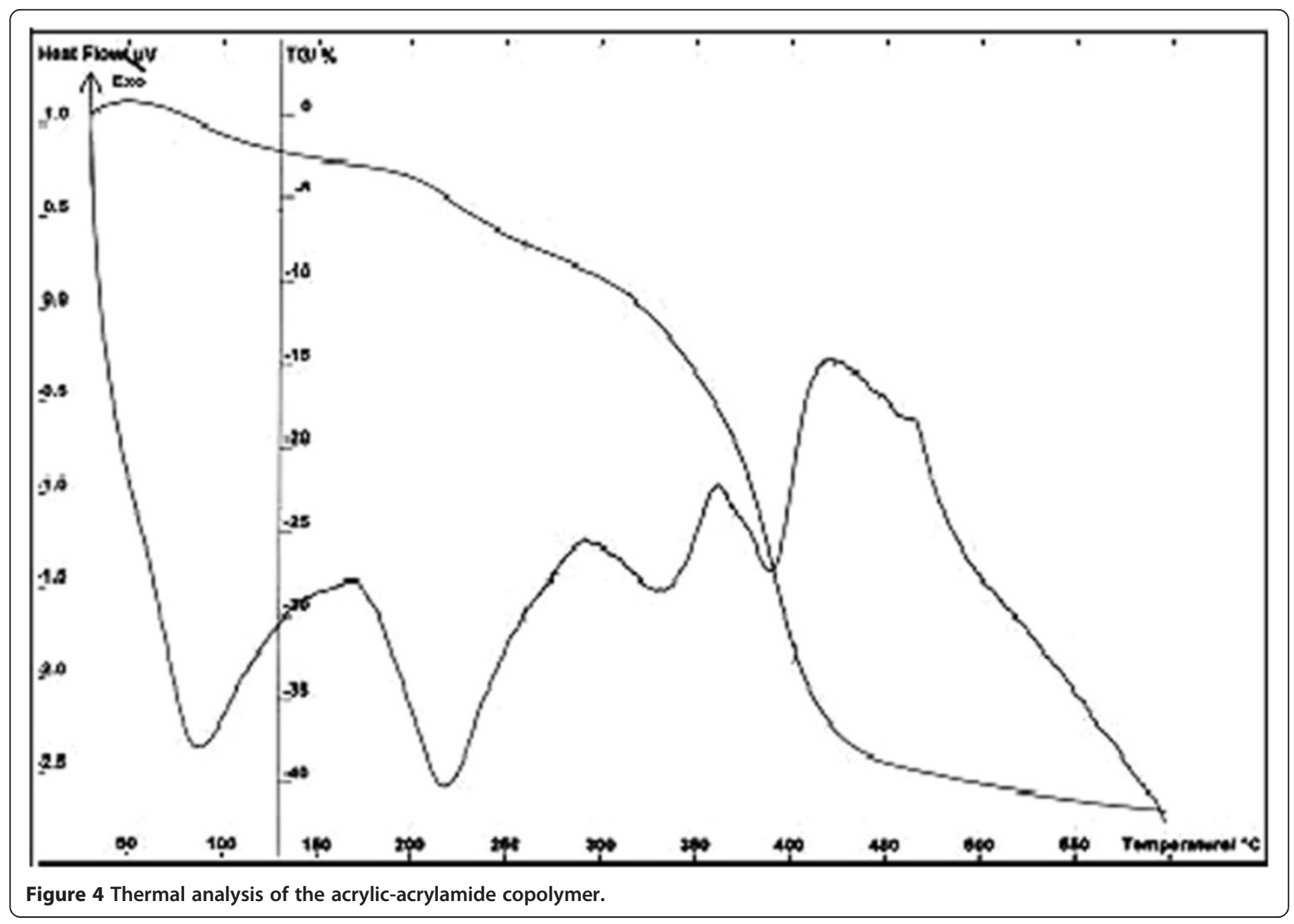




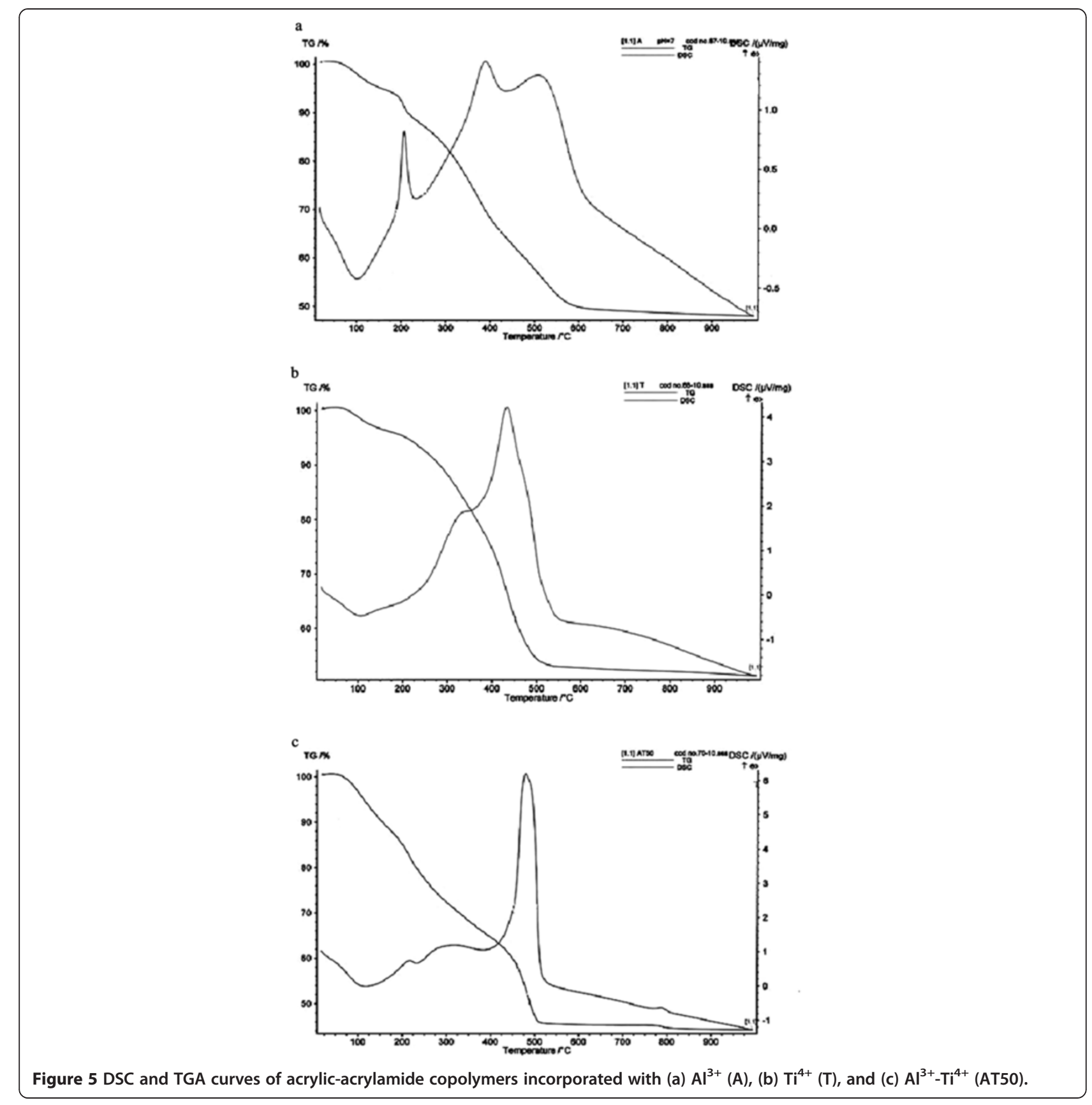

Table 2 Temperatures of the DSC peaks of the free polymer and those incorporated with $\mathrm{Al}^{3+}$ and $\mathrm{Ti}^{4+}$

\begin{tabular}{|c|c|c|c|c|c|c|c|c|}
\hline \multirow[t]{2}{*}{ Material } & \multicolumn{4}{|c|}{ Endothermic peak temperature $\left({ }^{\circ} \mathrm{C}\right)$} & \multicolumn{4}{|c|}{ Exothermic peak temperature $\left({ }^{\circ} \mathrm{C}\right)$} \\
\hline & First & Second & Third & Fourth & First & Second & Third & Fourth \\
\hline Free polymer & 85 & 217 & 334 & 389 & 420 & - & - & - \\
\hline$+\mathrm{Al}^{3+}$ & 102 & - & - & - & 207 & 388 & 508 & - \\
\hline$+\mathrm{Al}^{3+}$ and $\mathrm{Ti}^{4+}$ & 118 & 232 & - & - & 479 & 787 & - & - \\
\hline$+\mathrm{Ti}^{4+}$ & 106 & - & - & - & 433 & - & - & - \\
\hline
\end{tabular}


Table 3 Temperatures of the main weight loss steps in the TGA curves of the polymers

\begin{tabular}{|c|c|c|c|c|c|c|c|c|}
\hline \multirow[t]{3}{*}{ Material } & \multicolumn{8}{|c|}{ Main steps } \\
\hline & \multicolumn{2}{|c|}{ Step I } & \multicolumn{2}{|c|}{ Step II } & \multicolumn{2}{|c|}{ Step III } & \multicolumn{2}{|c|}{ Step IV } \\
\hline & $\begin{array}{c}\text { Temperature } \\
\left({ }^{\circ} \mathrm{C}\right)\end{array}$ & $\begin{array}{c}\text { Weight loss } \\
(\%)\end{array}$ & $\begin{array}{c}\text { Temperature } \\
\left({ }^{\circ} \mathrm{C}\right)\end{array}$ & $\begin{array}{l}\text { Weight loss } \\
(\%)\end{array}$ & $\begin{array}{c}\text { Temperature } \\
\left({ }^{\circ} \mathrm{C}\right)\end{array}$ & $\begin{array}{c}\text { Weight loss } \\
(\%)\end{array}$ & $\begin{array}{c}\text { Temperature } \\
\left({ }^{\circ} \mathrm{C}\right)\end{array}$ & $\begin{array}{l}\text { Weight loss } \\
\text { (\%) }\end{array}$ \\
\hline Free polymer & 50 to 179 & 8 & 179 to 218 & 12 & 308 to 450 & 80 & & \\
\hline$+\mathrm{Al}^{3+}$ & 75 to 162.5 & 5.8 & 163 to 242.5 & 6.6 & 243 to 637 & 38.77 & 637 to 1,000 & 16.26 \\
\hline$+\mathrm{Al}^{3+}$ and $\mathrm{Ti}^{4+}$ & 50 to 175 & 12 & 175 to 378 & 22.3 & 378 to 550 & 20.42 & 775 to 1,000 & 1.27 \\
\hline$+\mathrm{Ti}^{4+}$ & 75 to 175 & 4.4 & 175 to 375 & 14.4 & 375 to 570 & 28.7 & 570 to 1,000 & 1.57 \\
\hline
\end{tabular}

stirring. A gel layer was deposited on the surface of the support by a dipping procedure. The obtained gel layers were left to dry at room temperature for $24 \mathrm{~h}$ followed by drying for $24 \mathrm{~h}$ at $80^{\circ} \mathrm{C}$. Finally, calcination of the prepared membranes took place at $700^{\circ} \mathrm{C}$ for $3 \mathrm{~h}$ in a temperature-programmable furnace with heating and cooling rates of $1.5^{\circ} \mathrm{C} / \mathrm{min}$. The deposition of the membrane layer was repeated three times as demonstrated in the flow chart in Figure 1.

\section{Grafting process}

Organo-silane products are used in surface modification to provide a convenient and stable means to create a hydrophobic ceramic surface and tailor the effective pore size (Miller and Koros 1990; Caro et al. 1998; Castricum et al. 2005; Javaid et al. 2001; Abidi et al. 2006; Hyun et al. 1996; Leger et al. 1996; Randon and Paterson 1997). Alkyl, chloro-alkyl, or fluoro-alkyl silanes of varying carbon chain lengths can be used to provide chemical affinity, to improve the separation performance, and to provide a specific degree of pore size reduction (Javaid et al. 2001). The prepared membranes were grafted using two different organo-silane compounds, namely octyltrichlorosilane and $\gamma$-aminopropyl-trimethoxysilane, to select the appropriate one for the process. The membrane samples were immersed in the silane solution of different concentrations $\left(2,5\right.$, and 10 vol.\% in ethanol) at room temperature $\left(25^{\circ} \mathrm{C}\right)$ and then dried at $70^{\circ} \mathrm{C}$ for $24 \mathrm{~h}$. The procedure was repeated twice for different time intervals: 24 and $72 \mathrm{~h}$, giving a total of $96 \mathrm{~h}$ of immersion time. This procedure was used to characterize hydrophobicity and also grafting efficiency. After the immersion, the membranes were rinsed with ethanol two times to remove any unreacted chemicals from the membranes and dried at $70^{\circ} \mathrm{C}$ for $24 \mathrm{~h}$. Finally, the membranes were stored at room temperature ready for characterization (Krajewski et al. 2006).

\section{Methods for characterization}

Thermal analysis, comprising both differential scanning calorimetry (DSC) and thermogravimetric analysis (TGA),

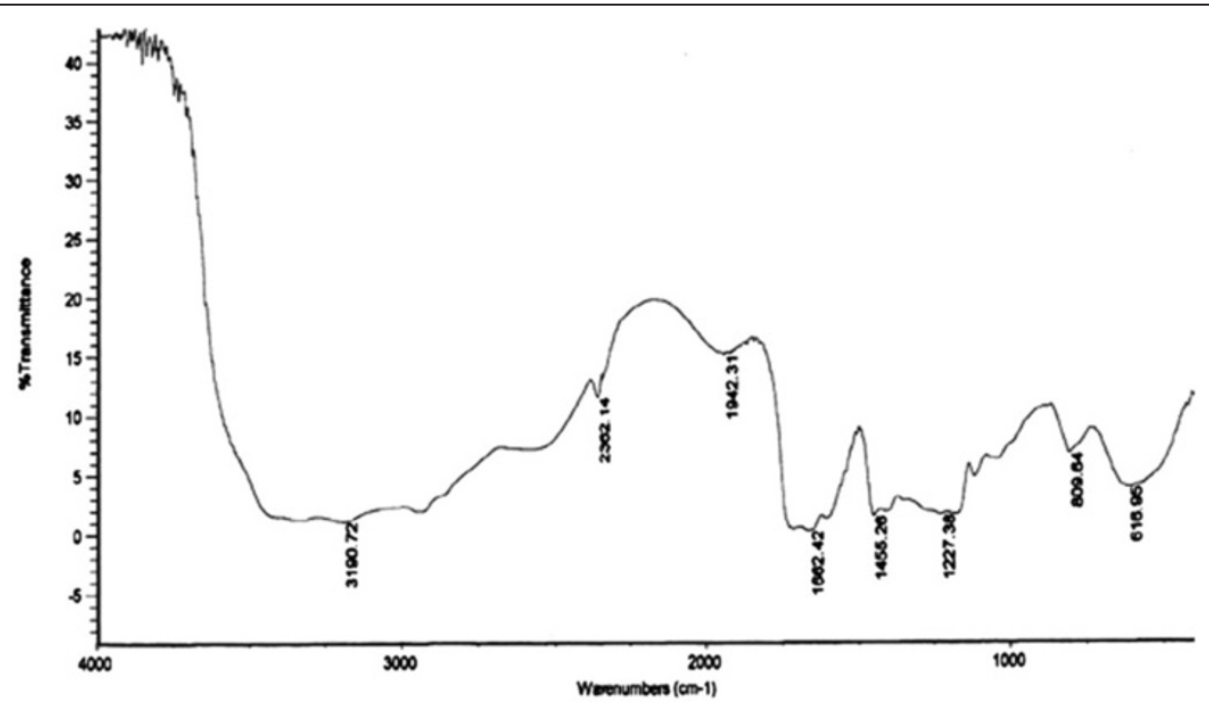

Figure 6 FTIR spectrum of the acrylic-acryl amide copolymer. 




Figure 7 FTIR spectra of different gels of alumina (A), titania (T), and alumina-titania (AT50).

a

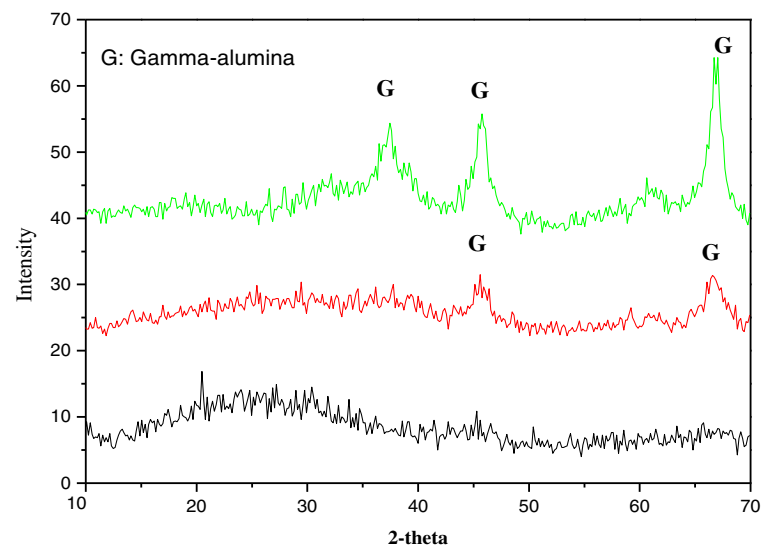

$\mathrm{b}$

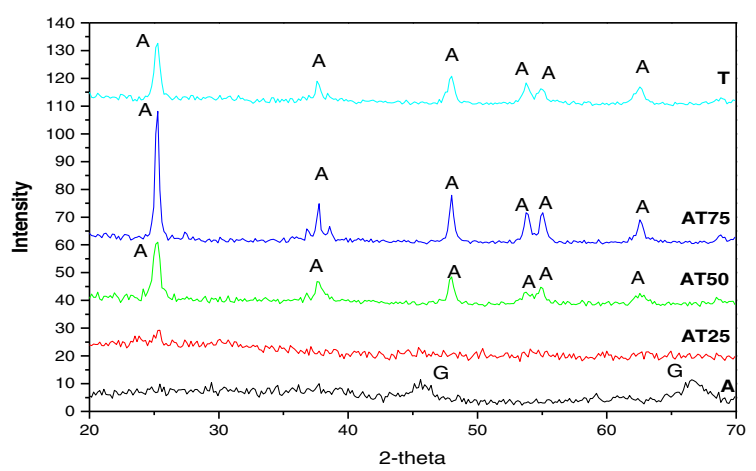

c

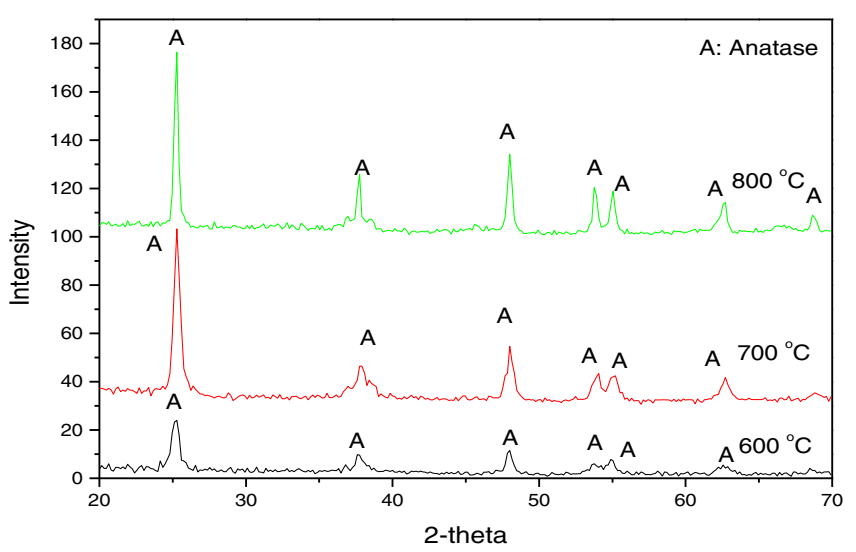

d

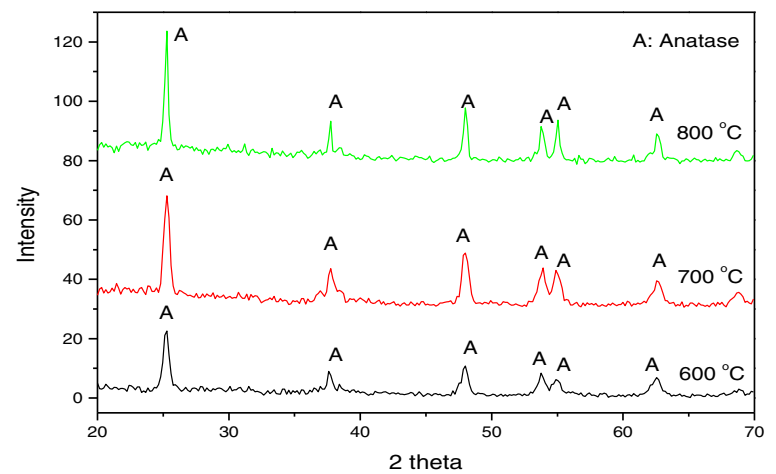

Figure 8 XRD patterns of the samples. (a) Alumina (A) powder calcined at $600^{\circ} \mathrm{C}, 700^{\circ} \mathrm{C}$, and $800^{\circ} \mathrm{C}$. (b) Alumina (A), alumina-titania (AT25, AT50, and AT75), and titania (T) membranes calcined at $700^{\circ} \mathrm{C}$, where $\mathrm{G}$ is gamma-alumina and $\mathrm{A}$ is anatase. (c) Alumina-titania (AT50) membrane calcined at $600^{\circ} \mathrm{C}, 700^{\circ} \mathrm{C}$, and $800^{\circ} \mathrm{C}$. (d) Titania (T) membrane calcined at $600^{\circ} \mathrm{C}, 700^{\circ} \mathrm{C}$, and $800^{\circ} \mathrm{C}$. 
was carried out on the acrylic-acrylamide copolymer and the dried membranes using a Setaram Labsys TM TGDSC16 system (Newark, CA, USA).

Fourier transform infrared (FTIR) spectroscopy equipment (MB154S, Bomem, Quebec, Canada) was used to determine the main bonds in the copolymer and the effect of the introduced inorganic cations to the polymer structure on the spectra of the different groups.

$\mathrm{X}$-ray diffraction analysis was carried out to characterize the respective alumina and titania phases developed in the membrane powder calcined at $600^{\circ} \mathrm{C}, 700^{\circ} \mathrm{C}$, and $800^{\circ} \mathrm{C}$ utilizing Bruker D8 (Madison, WI, USA) and $\mathrm{Cu}$ Ka radiation. Scanning was carried out at a rate of $1^{\circ}$ per minute in the $2 \theta$ range between $5^{\circ}$ and $70^{\circ}$.

The surface area measurements were performed using Quantachrome Instruments NOVA Automated Gas Sorption version 1.12 (Boynton Beach, FL, USA). $\mathrm{N}_{2}$ isotherms were performed at $77 \mathrm{~K}$ using a Coulter SA3 analyzer (Fullerton, CA, USA). The respective surface area values were calculated using the Brunauer-Emmett-Teller (BET) equation.

A transmission electron microscope (model JEOL JEM-1230, Akishima-shi, Japan) was used to examine the membrane powders with respect to their particle size and shape.
The distribution of pore size, pore area, and pore volume developed in the prepared membranes was determined using a Hg porosimeter (Type No. 9810). The chamber was first evacuated to a pressure less than 10 psia and then subjected to the introduction of a nonwetting liquid (mercury), under a hydraulic pressure of 14 to $415 \mathrm{~Pa}$, corresponding to pore radii from approximately $2 \mathrm{~nm}$ to approximately $200 \mu \mathrm{m}$.

The morphological characteristics of the membrane surface and the thickness of the prepared layer after and before the grafting process were examined using scanning electron microscopy (SEM) equipment (Philips XL30, Amsterdam, The Netherlands). The method is based on directing a fine-focused electron beam accelerated under a maximum potential difference of $30 \mathrm{kV}$ to scan the surface and microstructure of the specimen displayed on a cathode ray screen. The microstructure is then photographed at a magnification between $\times 200$ and $\times 50,000$.

The surface of the prepared membranes was treated to produce a kind of surface modification to maximize its degree of hydrophobicity by eliminating the existence of small, hydrophilic pores. This approach has been achieved through the treatment with chloro-alkyl silanes that enhanced surface flow and solution diffusion.

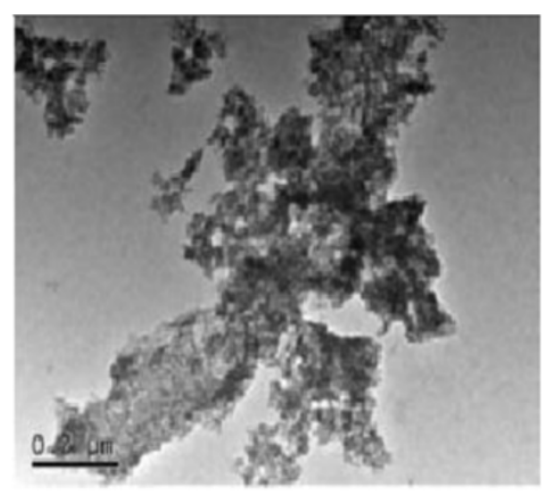

(a)


Figure 9 TEM images $(a, b, c)$ and electron diffraction pattern (d) of the alumina (A) membrane powder fired at $700^{\circ} \mathrm{C}$. 


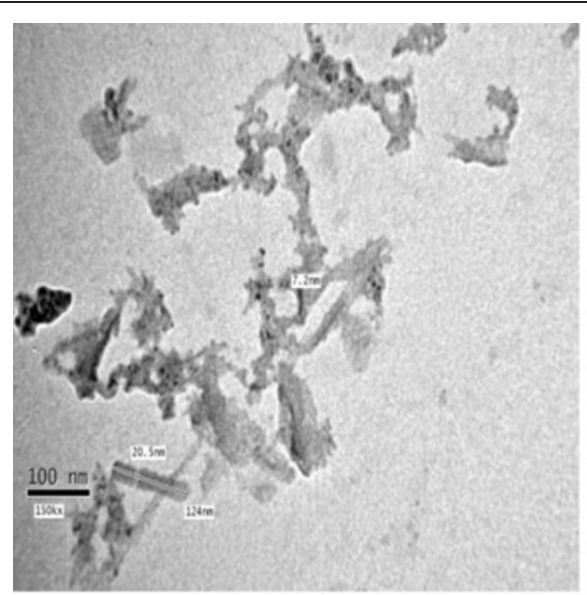

(a)

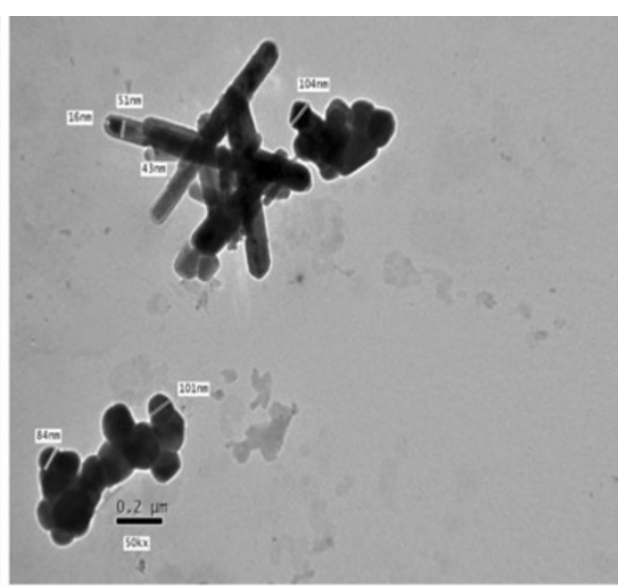

(b)

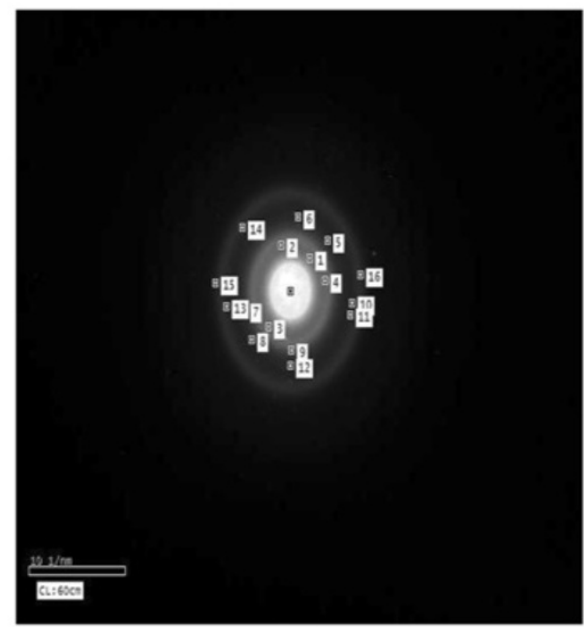

(c)

Figure 10 TEM images $(a, b)$ and electron diffraction pattern (c) of the alumina-titania (AT50) membrane powder fired at $700^{\circ} \mathrm{C}$.

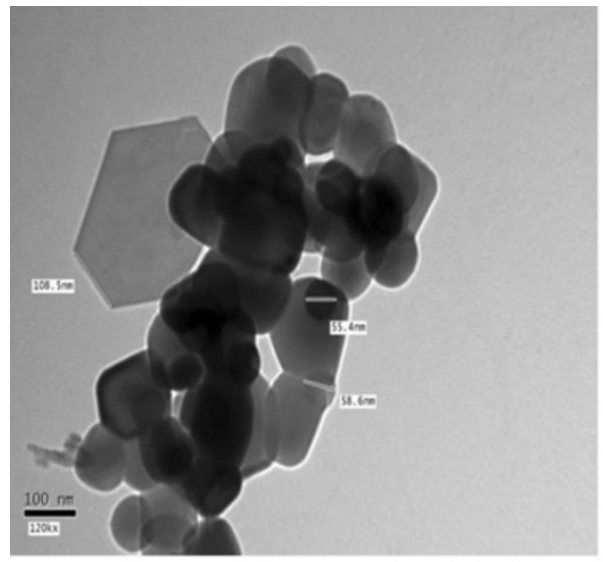

(a)

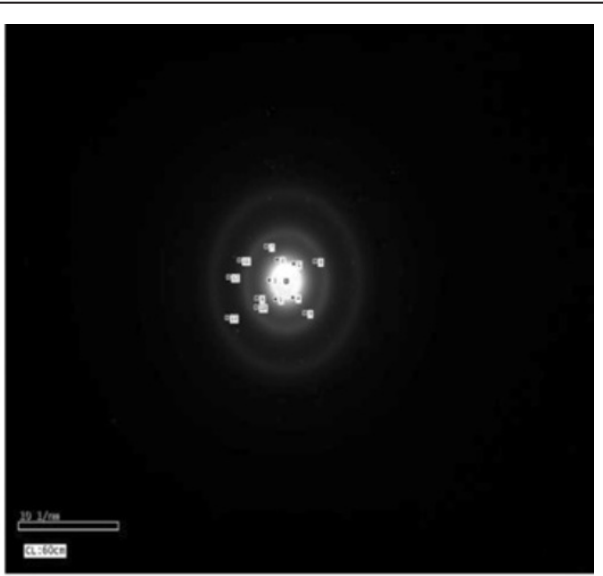

(b)

Figure 11 TEM image (a) and electron diffraction pattern (b) of the titania (T) membrane powder fired at $700^{\circ} \mathrm{C}$. 
The hydrophobic character of the prepared membranes was checked by measuring the contact angles of a sessile waterdrop on the membrane samples using a goniometer apparatus (Figure 2).

Water flux, permeability measurements, and salt rejection efficiency of the prepared membranes were performed using a homemade pilot plant, as shown in Figure 3.

The salt rejection efficiency of the prepared membranes was measured using a Hanna model conductivity electrode (model: HI99301). The retention coefficient $\left(R_{\mathrm{NaCl}}\right)$ was calculated according to the following equation:

$$
R_{\mathrm{NaCl}}=\left\{\left[\mathrm{CF}_{\mathrm{NaCl}}-\mathrm{CP}_{\mathrm{NaCl}}\right] / \mathrm{CF}_{\mathrm{NaCl}}\right\} \times 100 \%,
$$

where $\mathrm{CF}$ and $\mathrm{CP}$ denote the concentration of $\mathrm{NaCl}$ in both feed and permeate, respectively.

The desalination experiments were performed using the different prepared flat membranes, namely alumina (A), alumina-titania composite (AT25, AT50, AT75), and titania $(\mathrm{T})$. A fixed flow rate $(10 \mathrm{ml} / \mathrm{s})$ and vacuum pressure $(-0.8 \mathrm{bar})$ were used in the process. Three aqueous $\mathrm{NaCl}$ feed solutions were as follows: 2,000, 3,000, and 5,000 ppm.

The $\mathrm{NaCl}$ solutions were prepared and heated at different temperatures $\left(45^{\circ} \mathrm{C}, 55^{\circ} \mathrm{C}, 65^{\circ} \mathrm{C}\right.$, and $\left.75^{\circ} \mathrm{C}\right)$. The salt concentration of the permeate was measured in order to determine the respective retention coefficient. The temperature of the cooling condenser was maintained at $7^{\circ} \mathrm{C}$.

\section{Results and discussion}

\section{Thermal analysis}

The TGA and DSC of the acrylic-acrylamide copolymer alone and those incorporated with $\mathrm{Al}^{3+}$ or $\mathrm{Ti}^{4+}$ cations are shown in Figures 4 and 5, respectively. Weight loss and destruction of the acrylic-acrylamide copolymer take place in three steps: loss of water (moisture) followed by a gradual dissociation of the copolymer that ends by the combustion of the copolymer at $450^{\circ} \mathrm{C}$.

The DSC of the copolymer reveals four endothermic peaks. The glass transition temperature of the copolymer is at $85^{\circ} \mathrm{C}$, followed by its melting point at $217^{\circ} \mathrm{C}$. The third and fourth peaks at $334^{\circ} \mathrm{C}$ and $389^{\circ} \mathrm{C}$, respectively, are due to dissociation of the copolymer according to the polymer molecular weight. Decomposition of the copolymer occurs as an exothermic peak at $420^{\circ} \mathrm{C}$.

Figure 5a,b,c and Tables 2 and 3 show the TGA and DSC of the acrylic-acrylamide copolymer incorporated with alumina, titania, and alumina-titania composite, respectively. It was found that the thermogram of the acrylic-acrylamide copolymer incorporated with alumina, titania, and alumina-titania composite represents
Table 4 Surface area measurements for the different membrane powders calcined at $700^{\circ} \mathrm{C}$

\begin{tabular}{|c|c|c|c|c|}
\hline $\begin{array}{l}\text { Sample } \\
\text { ID }\end{array}$ & Type of membrane & $\begin{array}{c}\text { Temperature } \\
\left({ }^{\circ} \mathrm{C}\right)\end{array}$ & $\begin{array}{c}\text { Surface } \\
\text { area } \\
\left(\mathrm{m}^{2} / \mathrm{g}\right)\end{array}$ & $\begin{array}{c}\text { Particle } \\
\text { size } \\
(\mathrm{nm}) \\
\end{array}$ \\
\hline A & Alumina (100 mol\%) & 700 & 481.2 & 3.28 \\
\hline AT25 & $\begin{array}{l}\text { Alumina (75 mol\%)-titania } \\
\text { (25 mol\%) }\end{array}$ & 700 & 333 & 4.63 \\
\hline AT50 & $\begin{array}{l}\text { Alumina (50 mol\%)-titania } \\
\text { (50 mol\%) }\end{array}$ & 700 & 201.9 & 7.69 \\
\hline AT75 & $\begin{array}{l}\text { Alumina (25 mol\%)-titania } \\
\text { (75 mol\%) }\end{array}$ & 700 & 175.1 & 8.81 \\
\hline $\mathrm{T}$ & Titania (100 mol\%) & 700 & 324.9 & 4.98 \\
\hline
\end{tabular}

three stages of weight loss, as demonstrated before and illustrated in Table 3.

From Figure 5a, the glass transition temperature increased to $102^{\circ} \mathrm{C}$ and the softening point increased to $206.5^{\circ} \mathrm{C}$. Also, the polymer was completely degraded at $508^{\circ} \mathrm{C}$. Figure $5 \mathrm{~b}$ shows that the glass transition temperature and the softening point of the acrylicacrylamide copolymer coupled at $106.1^{\circ} \mathrm{C}$, and the polymer was completely combusted at $570^{\circ} \mathrm{C}$. Figure $5 \mathrm{c}$ shows that the glass transition temperature and the softening point of the acrylic-acrylamide copolymer were at $117.9^{\circ} \mathrm{C}$ and $232.2^{\circ} \mathrm{C}$, respectively, while the polymer was combusted at $478.8^{\circ} \mathrm{C}$.

It is clear that all reaction temperatures: glass transition, softening point, and combustion, of the copolymer are shifted to higher temperatures. These increases are due to the reaction that occurred between the metal oxide and copolymer.

\section{Fourier transform infrared spectroscopy}

The IR spectrum of the acrylic-acrylamide copolymer is displayed in Figure 6. A broad band occurs at 2,500 to $3,500 \mathrm{~cm}^{-1}$ which is due to the combination of two broad bands corresponding to the stretching vibration of the amide group and the stretching vibration of the carboxylic group. The main bands corresponding to the presence of the $\mathrm{C}=\mathrm{O}$ group occur at 2,362 and $1,662 \mathrm{~cm}^{-1}$. The bending vibrations of $\mathrm{O}-\mathrm{H}$ and $\mathrm{N}-\mathrm{H}$

Table 5 Results of the surface area of the alumina membrane powders calcined at $600^{\circ} \mathrm{C}, 700^{\circ} \mathrm{C}$, and $800^{\circ} \mathrm{C}$

\begin{tabular}{lcccc}
\hline $\begin{array}{l}\text { Sample } \\
\text { ID }\end{array}$ & $\begin{array}{c}\text { Type of } \\
\text { membrane }\end{array}$ & $\begin{array}{c}\text { Temperature } \\
\left({ }^{\circ} \mathbf{C}\right)\end{array}$ & $\begin{array}{c}\text { Surface area } \\
\left(\mathbf{m}^{\mathbf{2}} \mathbf{/ g}\right)\end{array}$ & $\begin{array}{c}\text { Particle size } \\
(\mathbf{n m})\end{array}$ \\
\hline A & Alumina (100\%) & 600 & 812 & 1.89 \\
A & Alumina (100\%) & 700 & 481.2 & 3.28 \\
A & Alumina (100\%) & 800 & 282.7 & 5.99 \\
\hline
\end{tabular}


Table 6 Pore size distribution of the different membranes

\begin{tabular}{|c|c|c|c|c|c|c|}
\hline Sample symbol & $\begin{array}{c}\text { Total intrusion volume } \\
(\mathrm{ml} / \mathrm{g})\end{array}$ & $\begin{array}{c}\text { Total pore area } \\
\left(\mathrm{m}^{2} / \mathrm{g}\right)\end{array}$ & $\begin{array}{c}\text { Bulk density } \\
(\mathrm{g} / \mathrm{ml})\end{array}$ & $\begin{array}{l}\text { Average pore } \\
\text { diameter }(\mu \mathrm{m})\end{array}$ & $\begin{array}{c}\text { Apparent density } \\
(\mathrm{g} / \mathrm{ml})\end{array}$ & $\begin{array}{c}\text { Total porosity } \\
(\%)\end{array}$ \\
\hline Support & 0.2025 & 4.863 & 0.0914 & 2.2924 & 4.2786 & 46.42 \\
\hline $\begin{array}{l}\text { Hydrophobic } \\
\text { support }\end{array}$ & 0.1756 & 4.087 & 0.1719 & 2.3728 & 4.0677 & 41.67 \\
\hline $\begin{array}{l}\text { Intermediate } \\
\text { layer }\end{array}$ & 0.1547 & 3.116 & 0.2163 & 2.4669 & 3.9889 & 38.16 \\
\hline A & 0.0951 & 9.080 & 2.9666 & 0.0419 & 4.1316 & 28.27 \\
\hline AT25 & 0.0785 & 24.258 & 2.7355 & 0.0129 & 3.4830 & 21.46 \\
\hline AT50 & 0.0971 & 8.273 & 2.9119 & 0.0248 & 4.0595 & 28.27 \\
\hline AT75 & 0.0344 & 5.546 & 2.9833 & 0.0469 & 3.3249 & 34.32 \\
\hline T & 0.0998 & 35.464 & 2.5678 & 0.0113 & 3.3425 & 25.03 \\
\hline
\end{tabular}

groups attached to the polymer are found at 1,027 and $810 \mathrm{~cm}^{-1}$, respectively, while the main bands related to the rocking and bending vibrations of the $\mathrm{C}-\mathrm{H}$ bond are detected at 617 and $1,455 \mathrm{~cm}^{-1}$.

The IR spectra of the acrylic-acrylamide copolymer gels dried at $80^{\circ} \mathrm{C}$, incorporated with one or two cations, e.g., $\mathrm{Al}^{3+}, \mathrm{Ti}^{4+}$, and $\mathrm{Al}^{3+}-\mathrm{Ti}^{4+}$, are shown in Figure 7.

The high-frequency part of the spectrum is dominated by a broad band occurring between 3,000 and $3,500 \mathrm{~cm}^{-1}$ which is a characteristic of the -OH stretching mode of $\mathrm{COOH}$ groups in the 'acrylic-acrylamide copolymer' template polymer. The corresponding deformation modes appear in the range of 1,384 to $1,388 \mathrm{~cm}^{-1}$.

The IR spectra of the substituted cations with the functional groups of the template polymer are more or less similar with only slight variation. This indicates that the same reactions between the metal oxide and copolymer are taking place.

The bands at the range 624 to $659 \mathrm{~cm}^{-1}$ in the substituted copolymer spectra are attributed to the different inorganic cations' $\mathrm{R}^{+}-(\mathrm{O}-\mathrm{C})$ - stretching vibrations, where $\mathrm{R}^{+}=\mathrm{Al}^{3+}$ and $\mathrm{Ti}^{4}$.

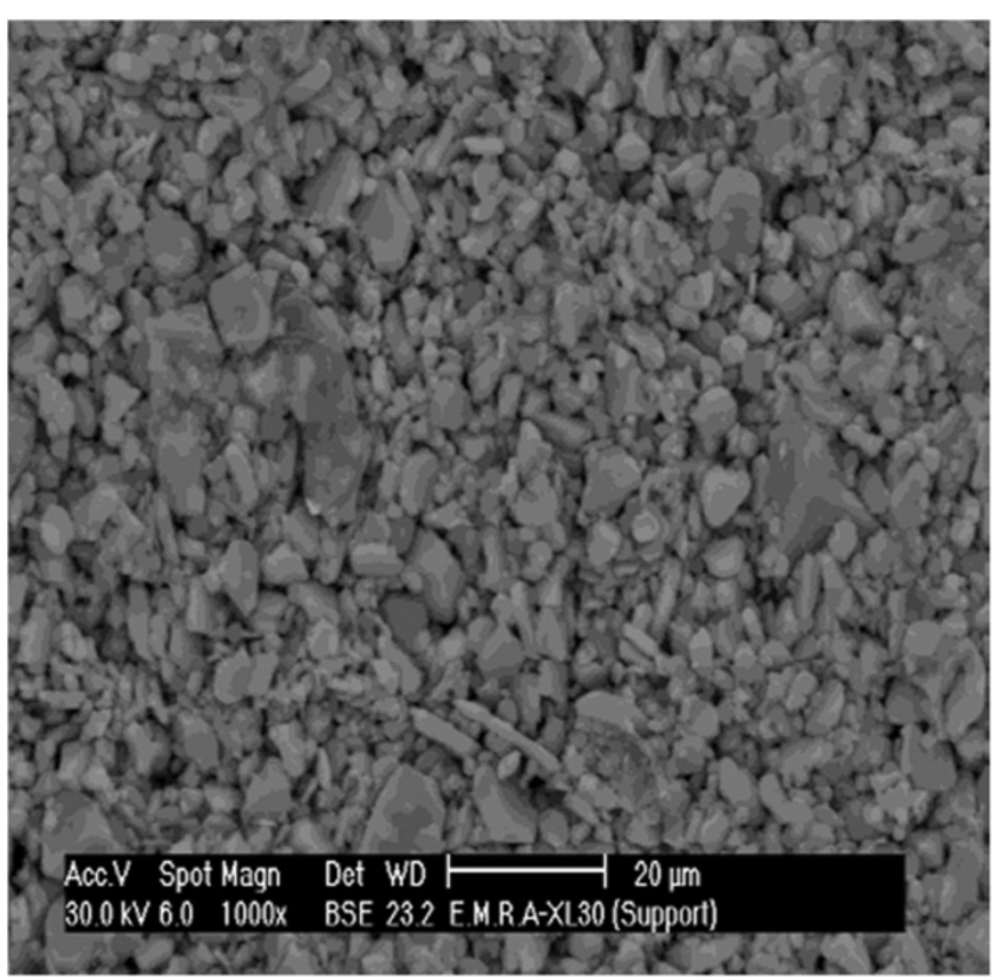

Figure 12 SEM image of the alumina support. 


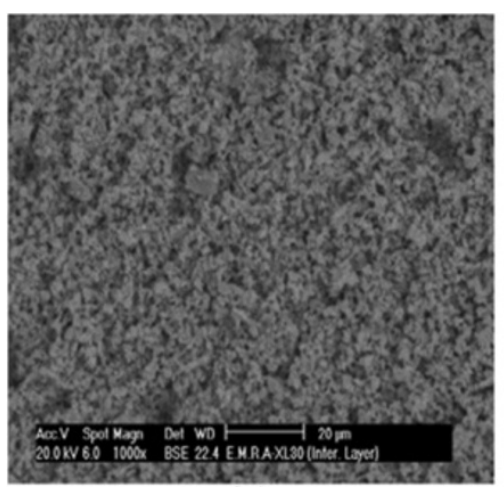

(a)

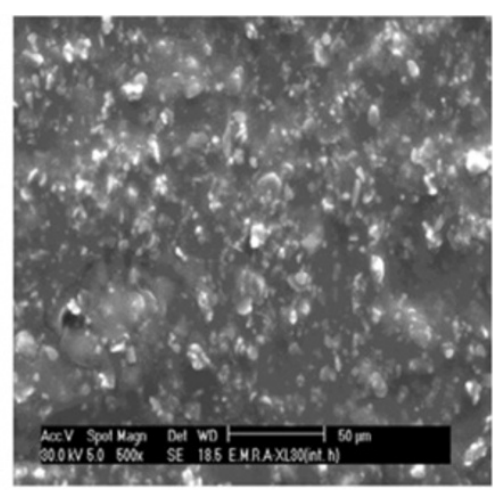

(b)

Figure 13 SEM images of both the (a) non-grafted and (b) grafted alumina intermediate layer.

The bands detected at 1,627 to $1,631 \mathrm{~cm}^{-1}$ correspond to the stretching mode of the $\mathrm{C}=\mathrm{O}$ functional group, whereas the $\mathrm{NH}$ and $\mathrm{OH}$ stretching vibrations occur in the same range $3,300 \mathrm{~cm}^{-1}$. Therefore, these bands failed to be distinguished from one another.

\section{X-ray diffraction analysis}

The X-ray diffraction (XRD) patterns of the different samples prepared using different molar ratios of the inorganic precursors $\left(\mathrm{AlCl}_{3}\right.$ and $\left.\mathrm{TiCl}_{4}\right)$ added to the template polymer (acrylic-acrylamide copolymer) and subjected to a calcination reaction at temperatures between $600^{\circ} \mathrm{C}$ and $800^{\circ} \mathrm{C}$ for $3 \mathrm{~h}$ are displayed in Figure $8 \mathrm{a}, \mathrm{b}, \mathrm{c}, \mathrm{d}$.

The XRD patterns of the alumina (A) powders heattreated at different temperatures: $600^{\circ} \mathrm{C}, 700^{\circ} \mathrm{C}$, and $800^{\circ} \mathrm{C}$, were ill crystalline at $600^{\circ} \mathrm{C}$, whereas the $\gamma$-alumina phase started to appear at $700^{\circ} \mathrm{C}$ showing an increase in the peak intensity at $800^{\circ} \mathrm{C}$, as shown in Figure $8 \mathrm{a}$.

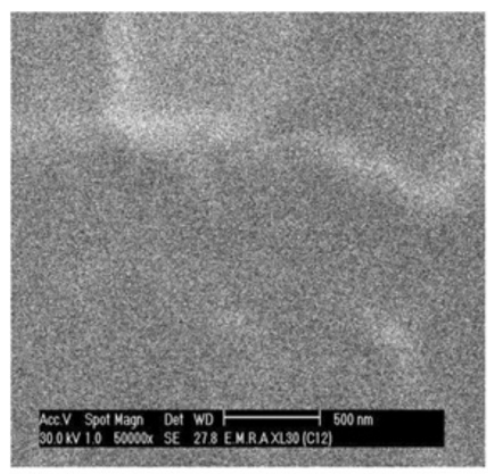

(a)

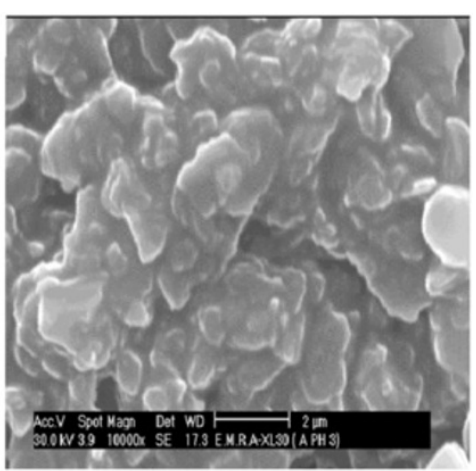

(b)

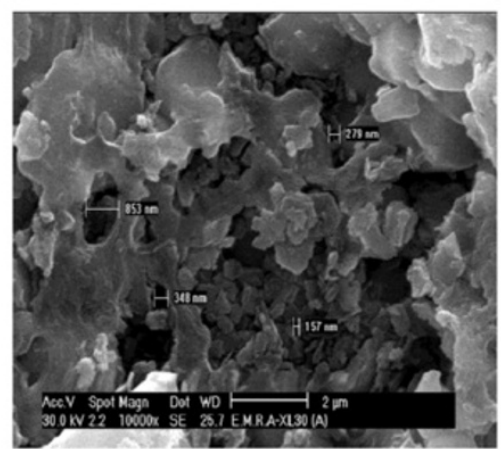

(c)

Figure $14 \mathrm{SEM}$ images of the alumina membranes calcined at different temperatures: (a) $600^{\circ} \mathrm{C}$, (b) $700^{\circ} \mathrm{C}$, and (c) $800^{\circ} \mathrm{C}$. 

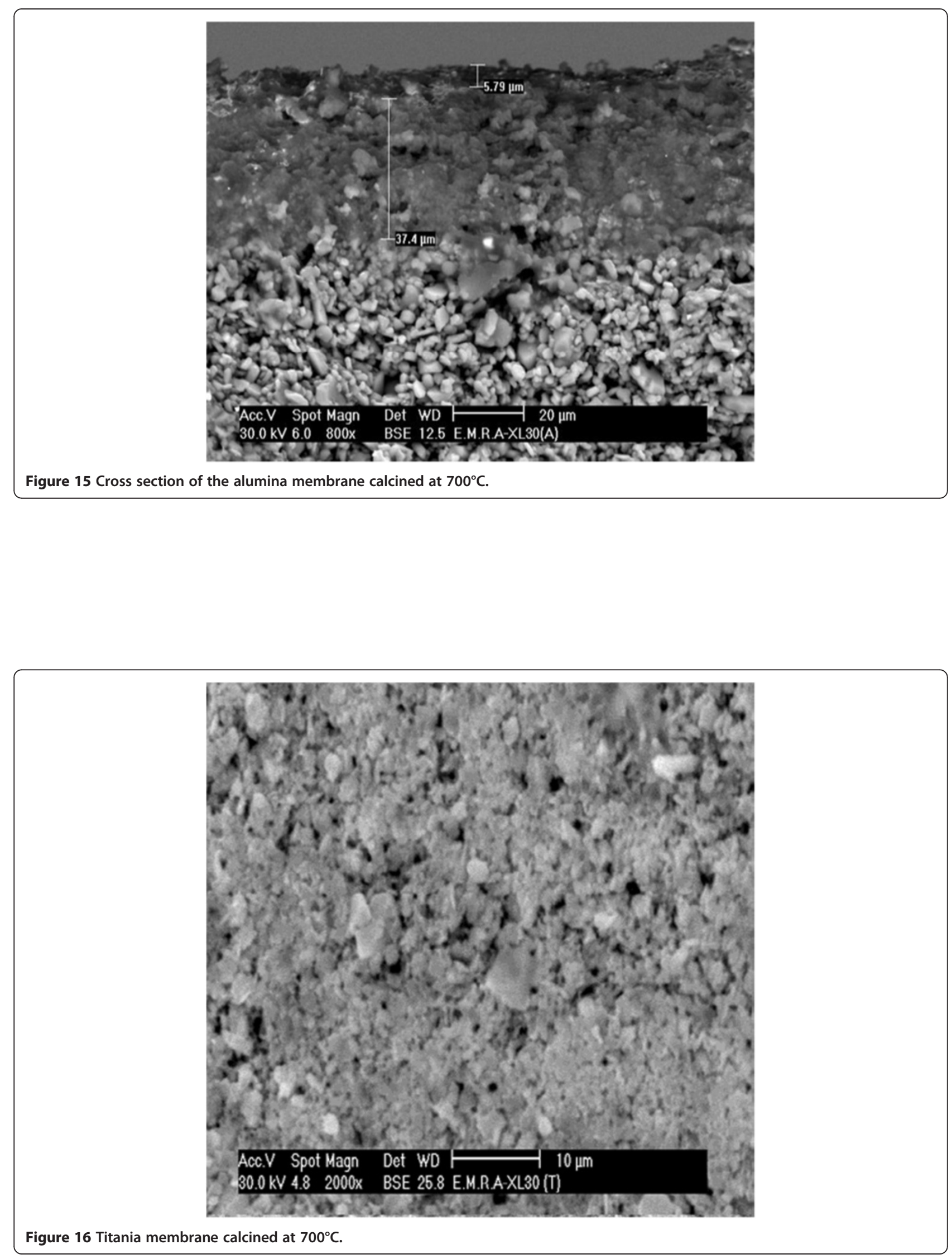
The XRD patterns of the membrane powders formed by alumina (A), alumina-titania (AT25, AT50, and AT75), and titania $(\mathrm{T})$ were heat-treated at $700^{\circ} \mathrm{C}$ are shown in Figure $8 \mathrm{~b}$. The XRD pattern of alumina indicates a small peak depicted at $2 \theta=67^{\circ}$ denoting the start of formation of the $\gamma$-alumina phase.

The XRD patterns of alumina-titania with different molar ratios of $\mathrm{AlCl}_{3} / \mathrm{TiCl}_{4}:$ 75\%:25\%, 50\%:50\%, and $25 \%: 75 \%$, exhibit a characteristic peak at $2 \theta=25^{\circ}$, attributed to the anatase phase beside that of $\gamma$-alumina. The intensity of the anatase peak increases with the increase of the proportion of titania concentration; as a result, the crystallization of the $\gamma$-alumina phase is retarded.

The XRD patterns of the alumina-titania (AT50) powders heat-treated at different temperatures are shown in
Figure $8 \mathrm{c}$. The alumina is ill crystalline at $600^{\circ} \mathrm{C}$, with the start of formation of the $\gamma$-alumina phase at $700^{\circ} \mathrm{C}$ and $800^{\circ} \mathrm{C}$. On the other hand, the titania crystallized as anatase in all powders heat-treated at $600^{\circ} \mathrm{C}$ up to $800^{\circ} \mathrm{C}$. The peak intensity increases with the increase of the temperature of the treatment.

The XRD patterns of the titania $(\mathrm{T})$ powders in Figure $8 \mathrm{~d}$ show the anatase phase at $600^{\circ} \mathrm{C}$ up to $800^{\circ} \mathrm{C}$. The intensity of the anatase peaks increases with the increase of the temperature of the treatment.

\section{Transmission electron microscopy}

Figures 9, 10, and 11 demonstrate the shapes of particles and overall appearance based on transmission electron microscopy of the prepared alumina, titania, and alumina-

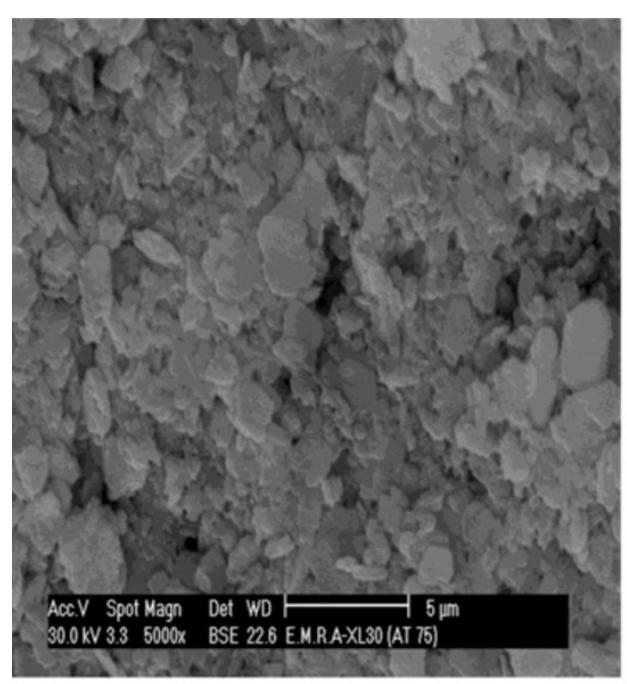

(a)

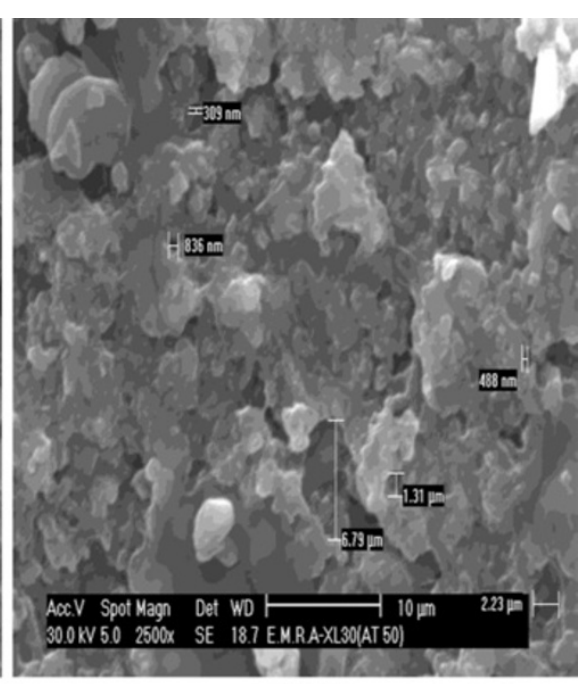

(b)



(c)

Figure 17 Alumina-titania composite membranes with different concentrations calcined at $700^{\circ} \mathrm{C}$. (a) Alumina (75 mol\%)-titania (25 mol\%) (AT25) membrane. (b) Alumina (50 mol\%)-titania (50 mol\%) (AT50) membrane. (c) Alumina (25 mol\%)-titania (75 mol\%) (AT75) membrane. 


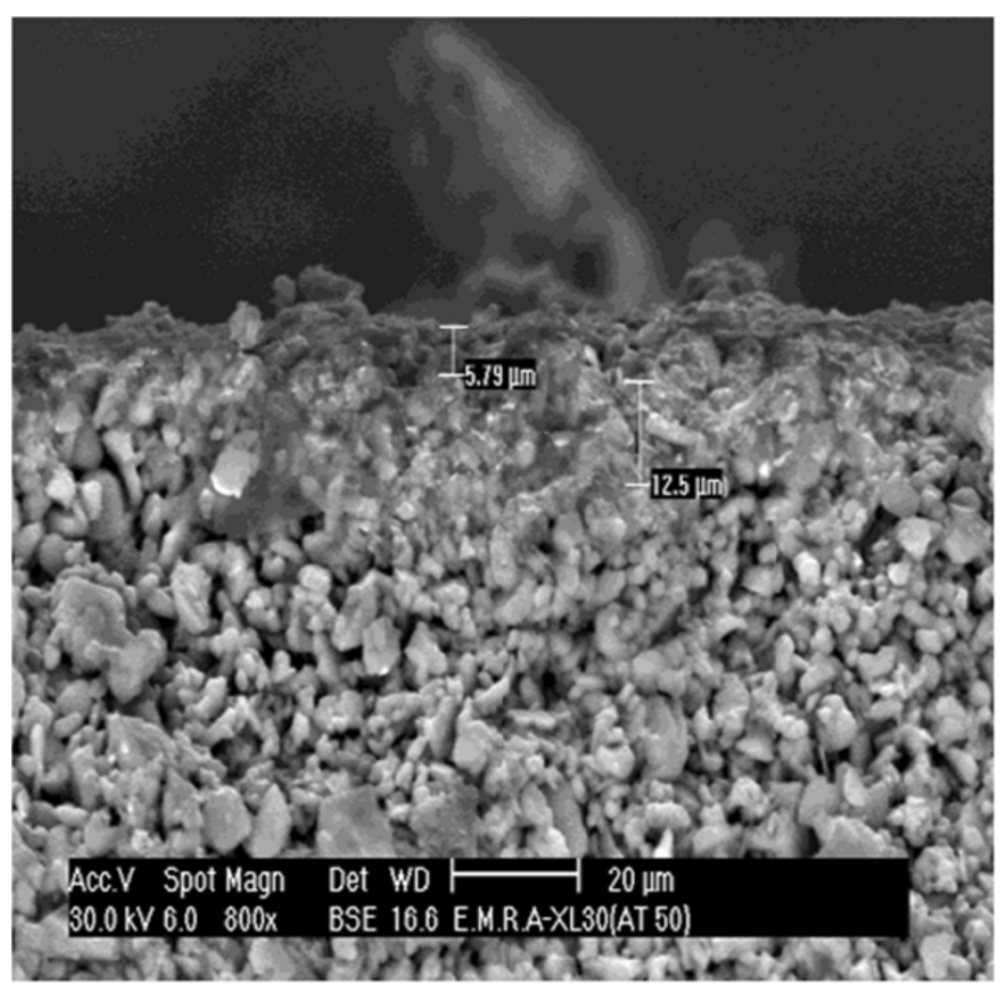

Figure 18 Cross section of the alumina-titania composite (AT50) membrane calcined at $700^{\circ} \mathrm{C}$.

titania composite membrane powders heat-treated at $700^{\circ} \mathrm{C}$ for $3 \mathrm{~h}$.

The TEM images of the alumina powder are shown in Figure 9a,b,c,d. Figure 9a shows a kind of agglomeration of the grains. The structure of the template polymer precursor was preserved by the substitution of the alumina cation as evident from the scattered dendrites. Figure 9b,c shows that the shape of the alumina grains ranged between spherical and rodlike with a size ranging from 65 to $95 \mathrm{~nm}$. The electron diffraction pattern of the powder showed diffuse rings indicating the illcrystalline nature of the grains with the presence of some spots presenting $\gamma$-alumina as demonstrated in Figure 9d.

The TEM images and electron diffraction pattern of the alumina-titania composite (AT) powder are shown in Figure 10a,b,c. The grains are agglomerated and arranged in a manner preserving the previous structure of the polymer, as demonstrated in Figure 10a, with a size ranging between 7 and $125 \mathrm{~nm}$ indicating the very fine nature of the powder. Figure 10b shows the shape of the particles that ranged between spherical and rodlike, with a size ranging between 16 and $104 \mathrm{~nm}$. On the other hand, the electron diffraction pattern of the powder shows the presence of diffuse rings attributed to the amorphous nature of the alumina, besides the presence of spots indicating the anatase phase of titania, as shown in Figure 10c.

The TEM image and electron diffraction pattern of the titania $(\mathrm{T})$ membrane powder in Figure 11a,b show agglomerates of the nano-grains with a size ranging

Table 7 Contact angle measurements of the alumina support modified with two different silane agents: $\mathrm{C3}$ and $\mathbf{C 8}$

\begin{tabular}{|c|c|c|c|c|c|}
\hline Number & Sample ID & $\begin{array}{l}\text { Concentration of } \\
\text { silane/ethanol } \\
\text { solution (vol.\%) }\end{array}$ & Side & $\begin{array}{c}\text { CA } \\
\text { (deg) }\end{array}$ & $\begin{array}{c}\text { Average } \\
\text { time (s) }\end{array}$ \\
\hline \multirow[t]{2}{*}{1} & C3 (2 vol.\%) & 2 & Front & 86.2 & \\
\hline & & & Back & & 8 \\
\hline \multirow[t]{2}{*}{2} & C3 (5 vol.\%) & 5 & Front & & 5 \\
\hline & & & Back & & 5 \\
\hline \multirow[t]{2}{*}{3} & C3 (10 vol.\%) & 10 & Front & & 6 \\
\hline & & & Back & & 11 \\
\hline \multirow[t]{2}{*}{4} & C8 (2 vol.\%) & 2 & Front & 102.2 & \\
\hline & & & Back & 115.7 & \\
\hline \multirow[t]{2}{*}{5} & C8 (5 vol.\%) & 5 & Front & 116.3 & \\
\hline & & & Back & 111.5 & \\
\hline \multirow[t]{2}{*}{6} & C8 (10 vol.\%) & 10 & Front & 107.4 & \\
\hline & & & Back & 106.1 & \\
\hline
\end{tabular}




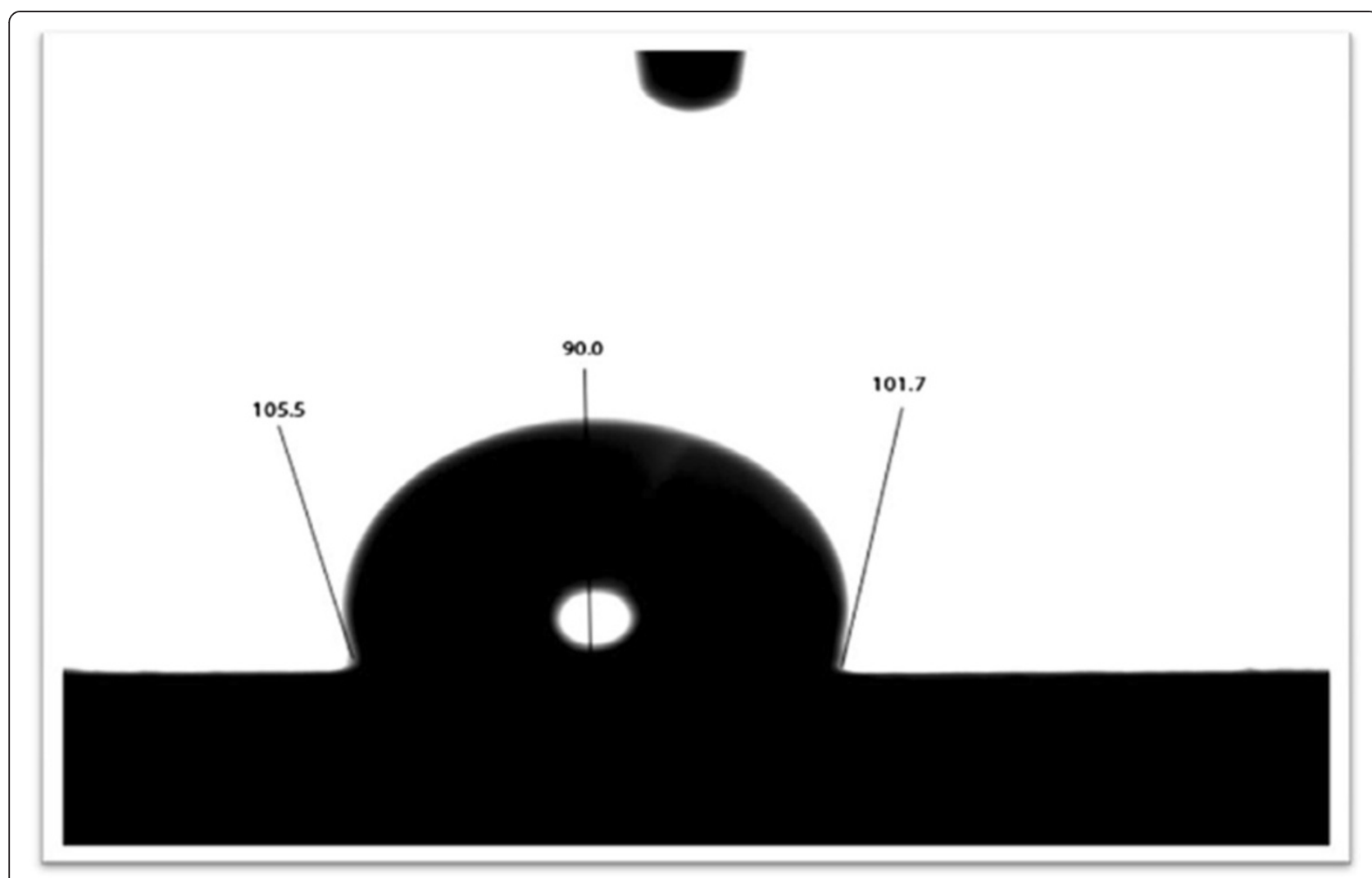

Figure 19 The waterdrop view on the hydrophobic surface of sample number 6 (one test).

between 55 and $108 \mathrm{~nm}$ indicating the fine nature of the powder. Particles are either spherical or hexagonal shaped. The electron diffraction pattern of the titania powder shows spots indicating the crystallization of the anatase phase.

\section{Specific surface area}

The results of the different membrane powders obtained after firing at $700^{\circ} \mathrm{C}$ in Table 4 indicate that the values of the specific surface area are affected by the type and molar ratio of the inorganic precursors reacted with the copolymer.

Powders of the alumina membranes heat-treated at $600^{\circ} \mathrm{C}, 700^{\circ} \mathrm{C}$, and $800^{\circ} \mathrm{C}$ gave the following values for the specific surface area: 812,481 , and $282.7 \mathrm{~m}^{2} / \mathrm{g}$, respectively, whereas the calculated particle sizes were $1.89,3.198$, and $5.889 \mathrm{~nm}$, as shown in Table 5 .

Powders of the alumina-titania composite heat-treated at $700^{\circ} \mathrm{C}$ showed a decrease in the values of the specific surface area with the increase in the concentration of titania precursors. Coarsening of the grains took place as evident from the calculated values recorded which increased from 4.6318 to $8.813 \mathrm{~nm}$, as shown in Table 4 .

\section{Pore size distribution}

The porosity and pore size distribution measurements of the prepared membranes are greatly affected by the alumina-titania ratios while those modified by octyltrichlorosilane show a slight decrease in the respective porosities and pore size measurements, as demonstrated in Table 6. This indicates that the organo-silane agent does not affect the whole structure, but only affect the surface properties.

The change in the average pore diameter of the support on grafting recorded was between 2.29 and $2.37 \mu \mathrm{m}$ and accompanied by a decrease in the total porosity from $46.42 \%$ to $41.67 \%$.

The recorded pore diameters of the alumina (A), alumina-titania (AT25, AT50, and AT75), and titania (T)

Table 8 Wetting angle measurements for the different grafted membranes

\begin{tabular}{lc}
\hline Membrane ID & Contact angle $\mathbf{( d e g )}$ \\
\hline A & Approximately 119 \\
AT50 & Approximately 120 \\
T & Approximately 123 \\
\hline
\end{tabular}




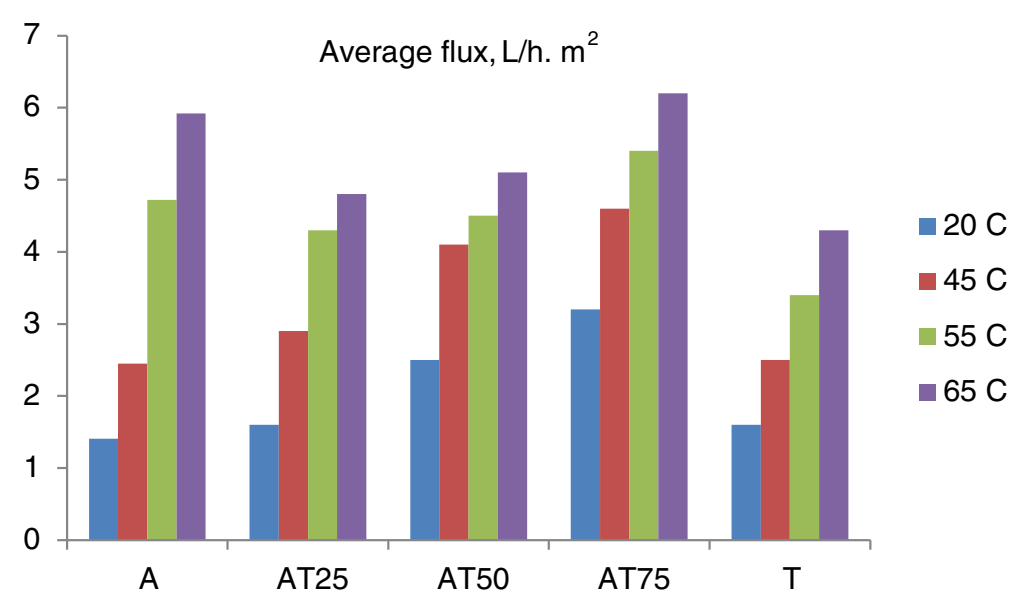

Figure 20 Permeate flux of water through the alumina, alumina-titania, and titania membranes at different temperatures.

membranes are in the following sequence: 41.9, 12.9, $46.9,24.8$, and $11.3 \mathrm{~nm}$, with respective porosity of $21.46 \%, 28.27 \%, 34.32 \%$, and $25.03 \%$.

\section{Scanning electron microscopy}

Microstructures of the main layers as well as the cross sections of the prepared membranes are shown in Figures 12, $13,14,15,16,17$, and 18 .

The SEM image in Figure 12 shows the surface of the alumina support specimen fired at $1,400^{\circ} \mathrm{C}$. The alumina grains with a size between 3 and $5 \mu \mathrm{m}$ show a coarse columnar to platy shape that is randomly oriented giving a porous microstructure with a rough and pitted surface. The interstices between the grains are filled with smaller ones about 1 to $2 \mu \mathrm{m}$.

The SEM images in Figure 13 show the outer surface of the grafted and non-grafted intermediate layer. The SEM image in Figure 13a shows the alumina support specimen covered with an $\alpha$-alumina intermediate layer (non-grafted sample) and fired at $1,000^{\circ} \mathrm{C}$. The coarse alumina grains are totally covered by the intermediate layer with a grain size ranging between 0.2 and $0.5 \mu \mathrm{m}$ with connected pores giving a smooth surface. The SEM image in Figure 13b shows the alumina support specimen covered with $\alpha$-alumina intermediate layer, fired at $1,000^{\circ} \mathrm{C}$, and grafted using octyltrichlorosilane. The covering layer displays the details of the underlying structure. No distinct behavior was spotted on the grafted surface.

The SEM images of the composite and monophase membranes in Figures 14, 15, 16, 17, and 18 show the effect of controlling the temperature profile of heat treatment and the concentration of the second phase on the elimination of microcracks and pinholes in the produced membranes to reduce the stresses originating from the removal of volatiles and the accompanying shrinkage.

The alumina membrane treated at $600^{\circ} \mathrm{C}$ in Figure $14 \mathrm{a}$ shows uniform and discrete layers. Increasing the temperature to $800^{\circ} \mathrm{C}$, as shown in Figure $14 \mathrm{c}$, leads to the formation of pinholes and cracks with coarsening of the grains through the agglomeration of the alumina particles to reach a size ranging between 348 and $853 \mathrm{~nm}$. Figure 14b, on the other hand, shows the improvement of the surface of the membrane layer heated at $700^{\circ} \mathrm{C}$, where these defects were diminished as possible with the presence of large alumina particles.

The SEM image of the cross section of the alumina (A) membrane in Figure 15 shows two different layers on top of the support: an intermediate layer with a thickness of $37.4 \mu \mathrm{m}$ followed by the alumina membrane layer with a thickness of $5.7 \mu \mathrm{m}$.

The SEM image of the titania membrane heat-treated at $700^{\circ} \mathrm{C}$ in Figure 16 shows the uniformity of the surface that completely covers the alumina support.

The effect of the addition of titania as a second component to form the composite membrane is shown in Figures 17 and 18.

Table 9 Permeate flux of water through the alumina, alumina-titania, and titania membranes at different temperatures

\begin{tabular}{lccccc}
\hline Temperature $\left({ }^{\circ} \mathbf{C}\right)$ & \multicolumn{5}{c}{ Average flux $\left(\mathbf{I} / \mathbf{h ~ m}^{2}\right)$} \\
\cline { 2 - 6 } & A & AT25 & AT50 & AT75 & T \\
\hline 20 & 1.4 & 1.6 & 2.5 & 3.2 & 1.51 \\
45 & 2.5 & 2.9 & 4.1 & 4.6 & 2.5 \\
55 & 4.7 & 4.3 & 4.5 & 5.4 & 3.4 \\
65 & 5.9 & 4.8 & 5.1 & 6.2 & 4.3 \\
\hline
\end{tabular}


The effect of the content of titania in the composite on the uniformity of the membrane layer is shown in Figure 17. A uniform surface of the alumina-titania composite (AT25) membrane heat-treated at $700^{\circ} \mathrm{C}$ is shown in Figure 17a. AT50 and AT75, on the other hand, show a kind of non-uniformity that might be generated by the stresses arising from the start of conversion of anatase to rutile phase, and this conversion is usually accompanied by grain growth of the latter phase, as shown in Figure 17b,c.

The SEM cross-sectional image of the aluminatitania composite (AT50) membrane as an example of the alumina-titania composite samples is shown in Figure 18. Two different layers appear on top of the support. The support is covered by an intermediate layer with a thickness of $12.5 \mu \mathrm{m}$ followed by the alumina-titania composite membrane layer with a thickness of $5.7 \mu \mathrm{m}$.

The SEM image of the surface of the alumina-titania (AT25) membrane showed a uniform crack-free top layer with the least pore diameter of $0.0129 \mu \mathrm{m}$ as demonstrated from the pore size distribution results.

\section{Contact angle measurements}

In the present work, two different organo-silane compounds, namely $\gamma$-aminopropyl-trimethoxysilane (C3) and octyltrichlorosilane $(\mathrm{C} 8)$, were selected to carry out the surface modification.

The grafted membranes (alumina (A), alumina-titania composite (AT), titania ( $\mathrm{T})$ ) obtained by immersion in a silane solution of different concentrations (2, 5, and 10 vol.\%) in an ethanol solution at room temperature $25^{\circ} \mathrm{C}$ were tested by measuring the contact angle developed on the surface. Also, these membranes were subjected for water permeation and water desalination. Therefore, the degree of water permeability and the rejection coefficient $(R \%)$ of the modified membranes were measured.

The results obtained shown in Table 7 represent an average of three readings for the tested membranes. An example of the drop formation and testing measurements is demonstrated in Figure 19.

The measured contact angles of the non-grafted supports are lower than $90^{\circ}$. Accordingly, they are considered hydrophilic and likely to absorb water. On the other hand, the measured contact angles of three alumina support samples grafted using $\gamma$-aminopropyl-trimethoxysilane denoted by $\mathrm{C} 3(2,5$, and $10 \mathrm{vol} . \%)$ are demonstrated in Table 7.

Accordingly, octyltrichlorosilane (C8, 5 vol.\%) was selected to graft the prepared ceramic membranes for the desalination measurements including water flux and rejection coefficient $(R \%)$ measurements for each membrane.
Table 10 The retention coefficient values of $\mathrm{NaCl}$ solutions through alumina, alumina-titania, and titania membranes

\begin{tabular}{lcccccc}
\hline \multirow{N}{*}{$\begin{array}{l}\text { NaCl } \\
\text { concentration } \\
(\mathbf{p p m})\end{array}$} & $\begin{array}{c}\text { Feed/permeate } \\
\text { temperature }\left({ }^{\circ} \mathbf{C}\right)\end{array}$ & \multicolumn{5}{c}{ Retention coefficient (\%) } \\
\cline { 3 - 7 } & & A & AT25 & AT50 & AT75 & T \\
\hline 2,000 & $45: 7$ & 19.58 & 26.30 & 28.51 & 11.5 & 10.67 \\
& $55: 7$ & 21.57 & 29.56 & 31.77 & 17.11 & 27.54 \\
& $65: 7$ & 32.52 & 41.55 & 38.69 & 19.17 & 38.96 \\
& $75: 7$ & 35.24 & 46.55 & 42.77 & 30.52 & 42.93 \\
3,000 & $45: 7$ & 26.2 & 28 & 30.79 & 15.31 & 24.27 \\
& $55: 7$ & 45.24 & 36.22 & 39.10 & 28.11 & 43.69 \\
& $65: 7$ & 47.62 & 44 & 46.43 & 29.32 & 53.79 \\
& $75: 7$ & 50.82 & 47.25 & 48.88 & 30.67 & 58.09 \\
5,000 & $45: 7$ & 34.44 & 53.02 & 32.99 & 16.87 & 53.58 \\
& $55: 7$ & 49.77 & 56.11 & 46.43 & 37.65 & 54.91 \\
& $65: 7$ & 51.39 & 63.58 & 60.49 & 40.09 & 56.23 \\
& $75: 7$ & 54.26 & 72.59 & 70.26 & 47.43 & 61.57 \\
\hline
\end{tabular}

The wetting angles of the different grafted membranes using 5 vol.\% octyltrichlorosilane (C8) indicated that the contact angle values recorded are independent of the membrane type as they show more or less the same contact angle, as shown in Table 8.

\section{Vacuum membrane distillation experiments Water permeation process}

The measured values of water flux through the prepared membranes depend on the temperature difference between the feed and permeate sides, as shown in Figure 20. Thus, the alumina membrane showed a gradual increase in water flux from 1.4 to $3.9 \mathrm{l} / \mathrm{h} \mathrm{m}^{2}$ when the temperature was raised gradually from $20^{\circ} \mathrm{C}$ to $65^{\circ} \mathrm{C}$.

The results in Table 9 compare water fluxes through the different grafted membranes (alumina (A), aluminatitania (AT25, AT50, AT75), titania (T)). It is evident from these results that water flux slightly depends on the pore diameter of the used membrane. The water fluxes of 1.58 and $1.5 \mathrm{l} / \mathrm{h} \mathrm{m}^{2}$ measured at $20^{\circ} \mathrm{C}$ were recorded through the AT25 and T membranes with an average pore diameter of 12.9 and $11.3 \mathrm{~nm}$, respectively.

These values were smaller than those reported for other alumina (A) and alumina-titania composite types

Table 11 Comparison between values of retention coefficient of $\mathrm{NaCl}$ solution $\left(5,000 \mathrm{ppm}\right.$ at $\left.75^{\circ} \mathrm{C}\right)$ using the different membranes

\begin{tabular}{lccccc}
\hline & \multicolumn{5}{c}{ Membrane type } \\
\cline { 2 - 6 } & A & AT25 & AT50 & AT75 & T \\
\hline Retention coefficient (\%) & 54.26 & 72.59 & 70.26 & 47.43 & 61.57 \\
\hline
\end{tabular}




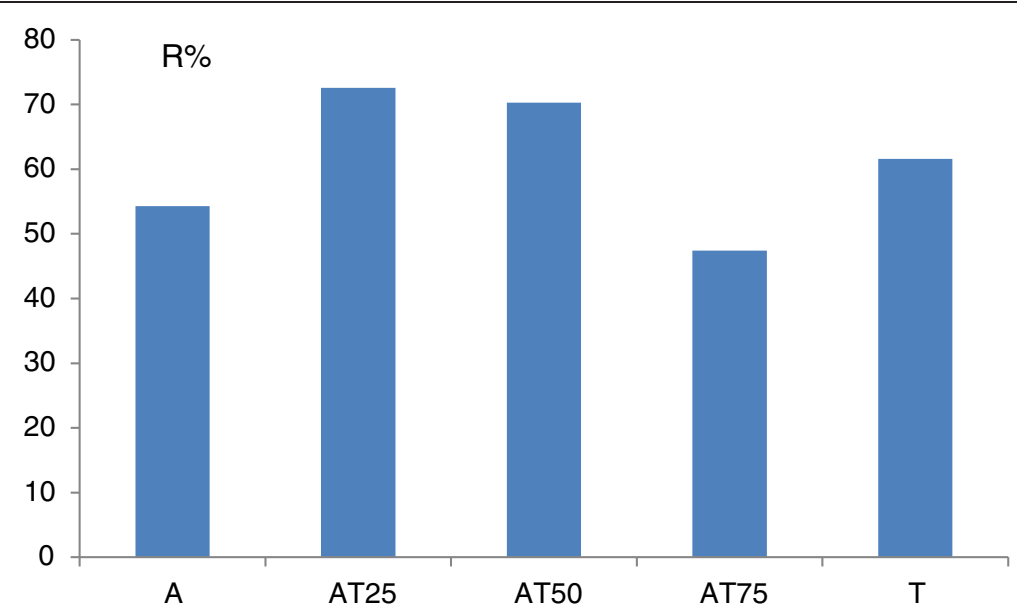

Figure 21 Comparison between retention coefficient values of $\mathrm{NaCl}$ solution $\left(5,000 \mathrm{ppm}\right.$ at $\left.75^{\circ} \mathrm{C}\right)$ using the different membranes.

(AT50 and AT75) of 4, 2.5, and 4.2 $\mathrm{l} / \mathrm{h} \mathrm{m}^{2}$ measured at $20^{\circ} \mathrm{C}$ with an average pore diameter of $41.9,24.8$, and $46.9 \mathrm{~nm}$, respectively.

\section{Desalination process}

The retention coefficient values $(R \%)$ of the different grafted membranes are presented in Table 10 which depended strongly on the temperature difference between the feed and the permeate side and on the concentration of the $\mathrm{NaCl}$ solution. The alumina membrane shows a retention coefficient of $34,49.7,51.39$, and 54.26 at a temperature difference of $45: 7,55: 7,65: 7$, and $75: 7$, respectively.

The retention coefficient values $(R \%)$ showed an increase by increasing the concentration of the $\mathrm{NaCl}$ solution. The retention coefficient $(R \%)$ of the alumina membrane increased from $35.24 \%$ to $54.2 \%$ by increasing the $\mathrm{NaCl}$ solution concentration from 2,000 to 5,000 ppm.

The alumina-titania composite (AT25 and AT50) and titania $(\mathrm{T})$ membranes showed a higher ability to reject the $\mathrm{NaCl}$ salt from water showing a retention coefficient of $72.59 \%, 70.26 \%$, and $61.57 \%$, respectively, while the alumina-titania composite AT75 showed a lower retention coefficient of $47.43 \%$.

Figure 21 and Table 11 show the salt retention $\left(R_{\mathrm{NaCl}}\right)$ during the membrane distillation process using the different grafted membranes (A, AT25, AT50, and T) at the temperature difference of $75: 7$ using $\mathrm{NaCl}$ solution of $5,000 \mathrm{ppm}$ as a feed solution. It can be seen that the salt retention coefficient in the MD process with the different prepared grafted membranes is close to $75 \%$. This can be explained by the fact that some of the biggest pores were wetted and limited transport of $\mathrm{NaCl}$ solution could occur.

\section{Conclusions}

The study of the preparation of membranes via the application of the acrylic-acrylamide copolymer as template was successful in overcoming the presence of cracks through the different additions. It was possible to obtain membrane layers of uniform nano-pore size and porosities between $25 \%$ and $37 \%$ fired at $700^{\circ} \mathrm{C}$. The crystal and morphological structures of the alumina-titania membranes were affected by the $\mathrm{AlCl}_{3}$ and $\mathrm{TiCl}_{4}$ feed ratio. The addition of titania succeeded in hindering the crystallization of the alumina phases and eliminating the possibility of the accompanying cracking. The polymeric route using acrylic-acrylamide copolymer as a template polymer led to preparation of membranes with ill-crystalline nature at $600^{\circ} \mathrm{C}$ that started to crystallize at $700^{\circ} \mathrm{C}$ which showed high surface area values as well as nano-pore size and mesoporosities. The results of water permeation showed that there is an upper limit for the addition of titania. The final supported membranes prepared using alumina-titania (AT25 and AT50) precursors showed uniform layers without cracks. The alumina-titania composite (AT) membranes showed a pore size of 13 to $46 \mathrm{~nm}$, porosity of $21 \%$ to $34 \%$, and water permeability of 2 to $8 \mathrm{l} / \mathrm{h} \mathrm{m} \mathrm{m}^{2} / \mathrm{bar}$. These membranes can be used for ultrafiltration purposes, such as pretreatment of water desalination and concentration of aqueous solutions (fruit juice, sugar solution). The polymeric solgel method used in this study to produce different hydrophobic alumina-titania membranes which utilized chloride salts of aluminum and titanium using acrylic-acrylamide as a template polymer and octyltrichlorosilane as a grafting agent is promising and can be used for different membranes. 


\section{Competing interests}

The authors declare that they have no competing interests.

\section{Authors' contributions}

AMANY Gaber carried out the membrane prepration studies and drafted the manuscript. Doreya Ibrahim: participated in the design of the study and revese the manuscrpt. Fawzia Fahim: prepared the template polymer used in the study. Elham ELZANZTI: measure the permeability performance of the different prepared membranes. All authors read and approved the final manuscript

\section{Author details}

${ }^{1}$ Ceramic Department, National Research Centre, Cairo, Egypt. ${ }^{2}$ Polymers Department, National Research Centre, Cairo, Egypt. ${ }^{3}$ Chemical Engineering Department, National Research Centre, Cairo, Egypt.

Received: 7 May 2013 Accepted: 16 October 2013

Published: 01 Nov 2013

\section{References}

Abidi N, Sivade A, Bourret D, Larbot A, Boutevin B, Guida-Pietrasanta F, Ratsimihety A (2006) Surface modification of mesoporous membranes by fluoro-silane coupling reagent for $\mathrm{CO}_{2}$ separation. J Membr Sci 270:101

Benfer S, Popp U, Richter H, Siewert C, Tomandl G (2001) Development and characterization of ceramic nanofiltration membranes. Sep Purif Tech 22 (23):231-237

Benfer S, Árki P, Tomandl G (2004) Ceramic membranes for filtration applications - preparation and characterization. Adv Eng Mater 6(7):495-500

Caro J, Noack M, Kolsch P (1998) Chemically modified ceramic membranes. Micropor Mesopor Mat 22:321

Castricum HL, Sah A, Mittelmeijer-Hazeleger MC, ten Elshof JE (2005)

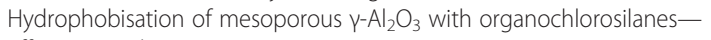
efficiency and structure. Microspor Mesopor Mat 83:1

Gaber AA (2007) Preparation of alumina membranes by sol-gel polymeric route. M.Sc Thesis, Cairo University

Hyun SH, Jo SY, Kang BS (1996) Surface modification of Y-alumina membranes by silane coupling for $\mathrm{CO}_{2}$ separation. J Membr Sci 120:197-206

Javaid A, Hughey MP, Varutbangkul V, Ford DM (2001) Solubility-based gas separation with oligomer-modified inorganic membranes. J Membr Sci 187:141

Krajewski SR, Kujawski W, Bukowska M, Picard C, Larbot A (2006) Application of fluoroalkylsilanes (FAS) grafted ceramic membranes in membrane distillation process of $\mathrm{NaCl}$ solutions. J Membr Sci 281:253-259

Kumar K-NP (1993) Nanostructured ceramic membranes; layer and texture formation. Ph.D. Thesis, University of Twente, Enschede, The Netherlands, p 113

Larbot A, Alami-Younssi S, Persin M (1994) Preparation of -alumina nanofiltration membrane. J Membr Sci 97:167

Leger C, Lira HDL, Paterson R (1996) Preparation and properties of surface modified ceramic membranes. Part III. Gas permeation of $5 \mathrm{~nm}$ alumina membranes modified by trichloro-octadecylsilane. J Membr Sci 120:187

Miller JR, Koros WJ (1990) The formation of chemically modified g-alumina microporous membranes. Sep Sci Technol 25:1257

Puhlfürß P, Voigt A, Weber R, Morbe M (2000) Microporous $\mathrm{TiO}_{2}$ membranes with a cut off $<500 \mathrm{Da}$. J Membr Sci 174:123

Randon J, Paterson R (1997) Preliminary studies on the potential for gas separation by mesoporous ceramic membranes modified by trichlorooctadecylsilane. J Membr Sci 120:187

Richter H, Piorra A, Tomandl G (1997) Developing of ceramic membranes for nanofiltration. Key Eng Mater 132-136:1715-1718

Schaep J, Vandecasteele C, Peeters B, Luyten J, Dotremont C, Roels D (1999)

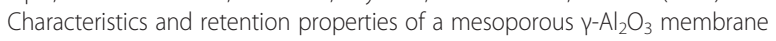
for nanofiltration. J Membr Sci 163:229

Sekulic J, Magraso A, ten Elshof JE, Blank DHA (2004) Influence of $\mathrm{ZrO}_{2}$ addition on microstructure and liquid permeability of mesoporous $\mathrm{TiO}_{2}$ membranes. Micropor Mesopor Mat 72:49-57
Shojai F, Mantyla TA (2001) Chemical stability of yttria doped zirconia membranes in acid and basic aqueous solutions: chemical properties, effect of annealing and ageing time. Ceram Int 27:299-307

van Gestel T, Vandecasteele C, Buekenhoudt A, Dotremont C, Luyten J, Leysen R, van der Bruggen B, Maes G (2002) Alumina and titania multilayer membranes for nanofiltration: preparation, characterization and chemical stability. J Membr Sci 207:73

van Gestel T, Vandecasteele C, Buekenhoudt A, Dotremont C, Luyten J, van der Bruggen B, Maes G (2003) Corrosion properties of alumina and titania NF membranes. J Membr Sci 214:21

Wildman DL, Peterson RA, Anderson MA, Hill CG (1994) Investigation of titania membranes for nanofiltration. In: Proceedings of the ICIM94. Worcester Polytechnic Institute, Worcester, p 111

Xu Q, Anderson MA (1993) Sol-gel route to synthesis of microporous ceramic membranes: thermal stability of $\mathrm{TiO}_{2}-\mathrm{ZrO}_{2}$ mixed oxides. J Am Ceram Soc 76:2093-2097

Zhang H, Banfield JF (1999) Synthesis and applications of $\mathrm{TiO}_{2}$ nanoparticles. Am Mineral 84:528.7.A

\subsection{6/2093-3371-4-18}

Cite this article as: Gaber et al: Synthesis of alumina, titania, and alumina-titania hydrophobic membranes via sol-gel polymeric route. Journal of Analytical Science and Technology 2013, 4:18

\section{Submit your manuscript to a SpringerOpen ${ }^{\odot}$ journal and benefit from:}

- Convenient online submission

- Rigorous peer review

- Immediate publication on acceptance

- Open access: articles freely available online

- High visibility within the field

- Retaining the copyright to your article

Submit your next manuscript at $>$ springeropen.com 